Article Title: Risks from climate-driven environmental changes to future atoll habitability

Article Type: Advanced review

\begin{tabular}{|c|c|}
\hline OPINION & PRIMER \\
\hline $\mathbf{x}$ ADVANCEd REVIEW & FOCUS ARTICLE \\
\hline & C OVERVIEW \\
\hline
\end{tabular}

Authors: The authors declare no conflict of interest.

\begin{tabular}{l} 
First author* \\
Virginie K.E. Duvat \\
ORCID number: 0000-0002-9336-3833 \\
UMR LIENSs 7266, La Rochelle University-CNRS, Bâtiment ILE, 2 rue Olympe de \\
Gouges, 17000 La Rochelle, France \\
virginie.duvat@univ-Ir.fr \\
\hline Second author \\
Alexandre K. Magnan \\
ORCID number: 0000-0001-7421-5184 \\
Institute for Sustainable Development and International Relations, Sciences-Po, \\
27 rue Saint-Guillaume, 75007, Paris, France \\
alexandre.magnan@iddri.org \\
\hline Third author \\
Chris T. Perry \\
ORCID number: 0000-0001-9398-2418 \\
Department of Geography, College of Life \& Environmental Sciences, University \\
of Exeter, EX4 4RJ, United Kingdom \\
C.Perry@exeter.ac.uk \\
\hline Fourth author \\
Tom Spencer \\
ORCID number: 0000-0003-2610-6201 \\
Cambridge Coastal Research Unit, Department of Geography, University of \\
Cambridge, Downing Place, Cambridge CB2 3EN, United Kingdom \\
ts111@cam.ac.uk \\
\hline Fifth author \\
Johann D. Bell \\
Pacific Tuna Fisheries, Conservation International \\
Australian National Centre for Ocean Resources and Security, University of \\
Wollongong, NSW 2522, Australia \\
\hline
\end{tabular}


jbell@conservation.org

Sixth author

Colette Wabnitz

ORCID number: 0000-0002-5076-9163

Institute for the Oceans and Fisheries, University of British Columbia, Vancouver, Canada

Stockholm Resilience Center, Stockholm University, Sweden

Center for Ocean Solutions, Stanford University, Stanford, California, United

States

c.wabnitz@oceans.ubc.ca

\section{Seventh author}

Arthur P. Webb

ORCID number: /

ANCORS (Australian National Centre for Ocean Resources \& Security), University of Wollongong, NSW, Australia

And

Tuvalu Coastal Adaptation Project (TCAP), Resilience \& Sustainable Development Unit, United Nations Development Programme, Level 7 Kadavu House, 414

Victoria Parade, Suva. Fiji

webbarthur@gmail.com

Eighth author

Ian White

ORCID number: 0000-0002-5455-4514

Australian National University, Fenner School of Environment and Society,

Fenner Building 141, Canberra, ACT 0200, Australia

Ian.White@anu.edu.au

\section{Ninth author}

Kathleen L. McInnes

ORCID number: 0000-0002-1810-7215

Climate Science Centre

CSIRO Oceans and Atmosphere

107-131 Station Street

Aspendale, 3195

Victoria, Australia

Kathleen.Mcinnes@csiro.au

\section{Tenth author}

Jean-Pierre Gattuso

ORCID number: 0000-0002-4533-4114

Sorbonne Université, CNRS, Laboratoire d'Océanographie de Villefranche, 181

chemin du Lazaret, 06230, Villefranche-sur-mer, France

Institute for Sustainable Development and International Relations, Sciences-Po,

27 rue Saint-Guillaume, 75007, Paris, France

gattuso@obs-vlfr.fr

\section{Eleventh author}

Nicholas A.J. Graham

ORCID number: 0000-0002-5332-0783 
Lancaster Environment Centre, Lancaster University, LA1 4YQ, United Kingdom

nick.graham@lancaster.ac.uk

Twelfth author

Patrick D. Nunn

ORCID number: 0000-0001-9295-5741

School of Social Sciences, University of the Sunshine Coast, Locked Bag 4, Maroochydore, Queensland 4558, Australia

pnunn@usc.edu.au

\section{Thirteenth author}

Gonéri Le Cozannet

BRGM, French Geological Survey, Risk and Prevention Department, Coastal Risks

and Climate Change Unit, 3 avenue Guillemin, 45000 Orléans, France

ORCID number: 0000-0003-2421-3003

G.LeCozannet@brgm.fr

\section{Abstract}

Recent assessments of future risk to atoll habitability have focused on island erosion and submergence, and have overlooked the effects of other climate-related drivers, as well as differences between ocean basins and island types. Here we investigate the cumulative risk arising from multiple drivers (sea-level rise; changes in rainfall, ocean-atmosphere oscillations and tropical cyclone intensity; ocean warming and acidification) to five Habitability Pillars: Land, Freshwater supply, Food supply, Settlements and infrastructure, and Economic activities. Risk is assessed for urban and rural islands of the Pacific and Indian Oceans, under RCP2.6 and RCP8.5, in 2050 and 2090, and considering a moderate adaptation scenario. Risks will be highest in the Western Pacific which will experience increased island destabilization together with a high threat to freshwater, and decreased land-based and marine food supply from reef-dependent fish and tuna and tuna-like resources. Risk accumulation will occur at a lower rate in the Central Pacific (lower pressure on land, with more limited cascading effects on other Habitability Pillars; increase in pelagic fish stocks) and the Central Indian Ocean (mostly experiencing increased land destabilization and reef degradation). Risk levels will vary significantly between urban islands, depending on geomorphology and local shoreline disturbances. Rural islands will experience less contrasting risk levels but higher risks than urban islands in the second half of the century. 


\section{Graphical/Visual Abstract and Caption}

\section{Climate change exposure Aggregated risk to atoll island habitability}

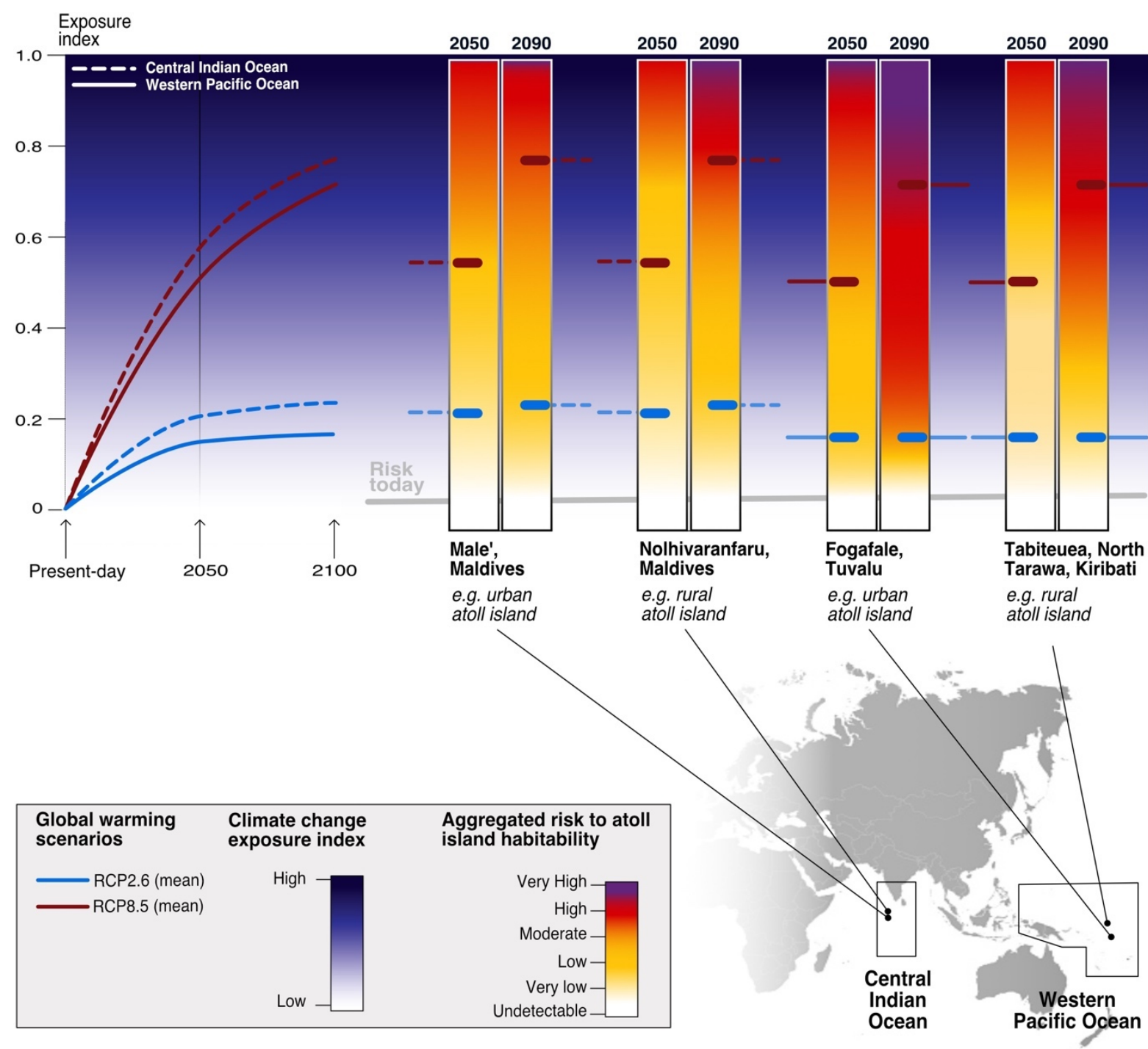

This figure displays the additional risk from climate change to future atoll island habitability. First, islands will experience different futures depending on their type (urban/rural) and region (Pacific/Indian ocean). Second, risk will increase even under a low emission scenario by the midcentury, therefore calling for urgent ambitious adaptation efforts. 


\section{Article title (advanced review): Risks from climate-driven environmental changes to future atoll habitability}

\section{INTRODUCTION}

Climate change impacts will increasingly compromise the essential dimensions of human life in lowlying tropical islands (Magnan et al., 2019). These dimensions include land, freshwater and food availability and the maintenance of settlements and infrastructure, as well as economic activities. The future of populations living on atoll islands in the Indian (Maldives) and Pacific Oceans (especially in the Cook Islands, Tuvalu, Federated States of Micronesia (FSM), Kiribati, Marshall Islands, Tokelau, French Polynesia; Supplementary Material SM1) will in part be determined by how the reef-island systems on which they depend will respond to changes in climate and ocean dynamics. Several recent assessments have focused on the risks of atoll island erosion and their temporary or permanent submergence under increased wave heights and accelerated sea-level rise (SLR; Oppenheimer et al., 2019), and some authors have suggested that these islands may become uninhabitable by 2060-90 under Representative Concentration Pathway (RCP) 8.5 due to annual flooding (e.g. Storlazzi et al., 2018; Giardino et al., 2018). Other studies have proposed that vertical accretion of shoreline systems may limit future flooding and its consequences for settlements (e.g. Beetham and Kench, 2018; Tuck et al., 2019).

These studies generally overlook the effects of drivers other than SLR, especially changes in rainfall and large-scale ocean-atmosphere oscillations, increasing tropical cyclone intensity, and ocean warming and acidification (Gattuso et al., 2015; Mentaschi et al., 2017; Vitousek et al., 2017; Perry et al., 2018; Oppenheimer et al., 2019). However, it is the combined effects of SLR and these drivers which control changes in island-scale reef growth, productivity and structure, terrestrial and marine food resources, and the availability of freshwater on atoll islands. Moreover, contemporary research has neither adequately considered differences in climate and ocean changes between ocean basins or even between islands (Nurse et al., 2014). Although we recognize that human factors, including socio-economic dynamics, human ingenuity, cultural change, population health crises, and geopolitics (e.g. Cinner et al., 2018), are also strong drivers of risks to atoll habitability, here we focus on climate-related environmental drivers and assess the extent to which their changes over the $21^{\text {st }}$ century are likely to compromise atoll habitability.

"Atoll islands" (islands herein) refer to recently-formed (generally $<4,000 \mathrm{yr} \mathrm{BP}$ ), low-lying (mean elevation generally $<3 \mathrm{~m}$ ) islands composed mostly of biologically derived carbonate sand, gravel and boulders, resting on reef structures at or near contemporary sea level and often encircling a central lagoon (Woodroffe, 2008; McLean, 2011; Gischler, 2016). Habitability of these islands is understood not only as "the ability of a place to support human life by providing protection from hazards which challenge human survival, and by assuring adequate space, food and freshwater" (Weyer et al., 2019, p. 15) but also as the ability of that place to provide economic opportunities, which contribute to health and well-being (Daw et al., 2015; Costanza et al., 2016; Bennett et al., 2019). Accordingly, the atoll island habitability framework (Fig. 1) presented here includes five major interrelated Habitability Pillars (HPs) that will all experience first-order (that is, direct) climate change impacts: i) availability of sufficient and safe land ('Land' herein); ii) supply of safe freshwater, especially from local sources ('Freshwater supply'); iii) supply of nutritious food from local and/or imported sources ('Food supply'); iv) access to safe settlements and infrastructure that sustains freedoms and opportunities, such as for trade, healthcare and education ('Settlements and infrastructure'); and v) access to sustainable economic activities ('Economic activities'). We evaluate the extent to which each of these HPs will be affected by future climate and ocean changes over the 21 st century, thereby increasing risks to life-supporting ecosystems and living conditions. We then assess the implications for future atoll habitability, from a biophysical and environmental 
perspective, as well as its variability across Indian and Pacific Oceans and across islands representing contrasting socio-economic situations (urban/rural).

Section 2 presents the Materials and Methods used. More particularly, it sheds light on HP significance, regions and islands of interest, climate threats considered, and the expert judgmentbased risk assessment protocol. Sections 3 and 4 present the Results, based on CMIP5 climate projections generated for RCPs 2.6 and 8.5 at 2050 and 2090. Section 3 highlights current and future threats to each HP, while Section 4 assesses the risk posed to habitability in four contrasting case study islands. Section 5 discusses the cumulative and cascading risks driven by climate change in atoll settings, as well as the spatial variations of risk to habitability across ocean regions and islands.
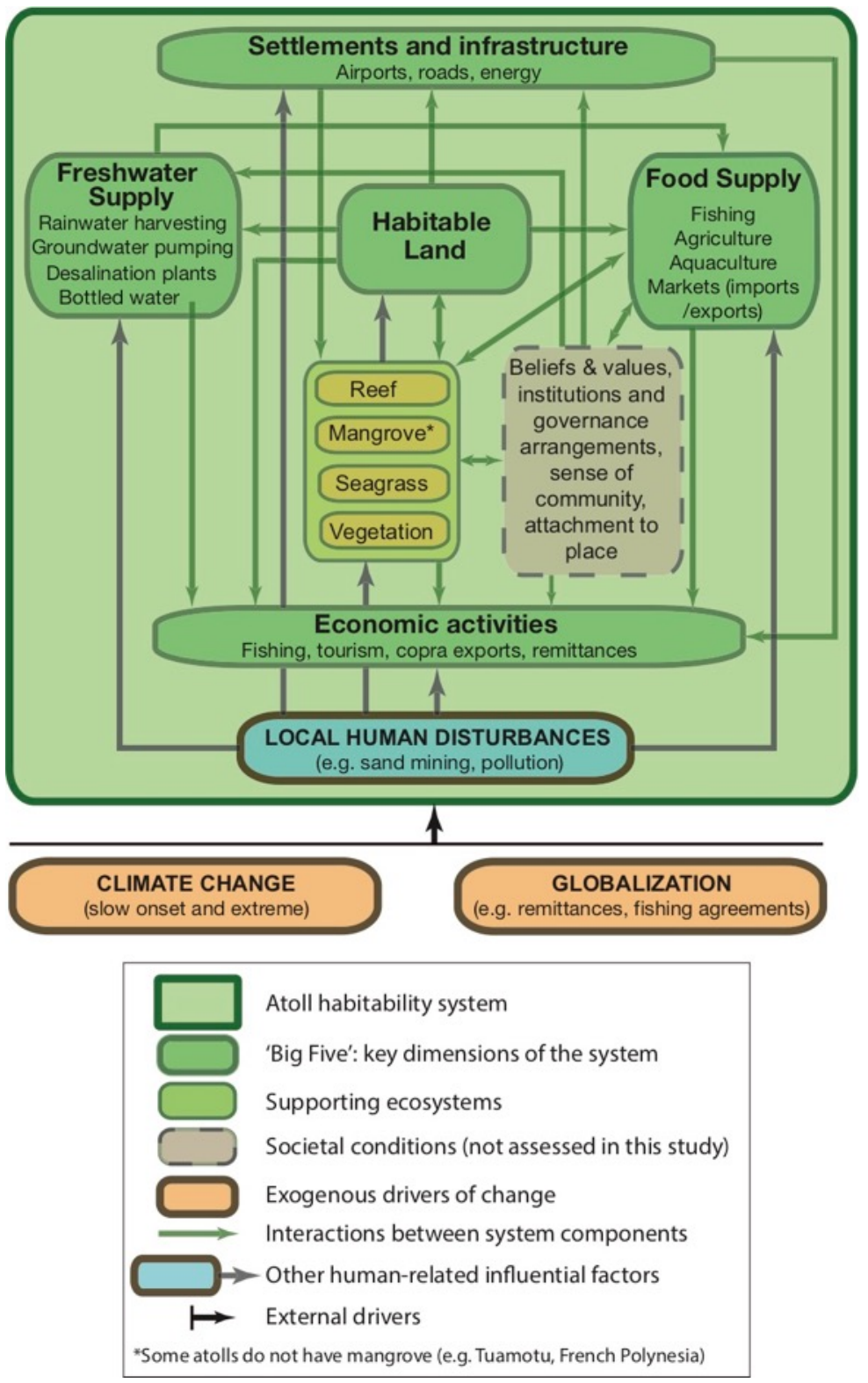

Figure 1. Conceptual model of atoll island habitability.

The atoll island system comprises five pillars supported by ecosystems and societal conditions. Interactions between these pillars are illustrated by green arrows: e.g. habitable land is critical to settlements and infrastructure, freshwater and food supply, economic activities, and natural vegetation development; in turn, the persistence of land is dependent on supporting ecosystems; thus the reef ecosystem provides the island with sediment and reduces wave energy reaching the coastline. Similarly, mangrove, seagrass and the natural strandline vegetation stabilize shoreline systems and can limit erosion and marine flooding. 


\section{MATERIALS AND METHODS}

This assessment relies on three main methods: a comprehensive literature review (especially using the databases Scopus and Web of Science); CMIP5 climate projections for the Indian and Pacific Oceans; and an expert judgment approach to evaluate the risks caused to each HP under the two most documented climate scenarios (RCPs 2.6 and 8.5) at 2050 and 2090. The overall analysis has benefited from the ten-to-thirty-year experience of the authors in atoll environments, in the research fields of geomorphology, ecology, hydrogeology, climate and impact modelling, subsistence and economic activities, development and sustainability. Two three-day workshops in September 2019 and February 2020 allowed for both the framing elements (HPs, geographical scope, case studies, climate scenarios and timescales; sections 2.1 to 2.3) and assessment method (including test phase; section 2.4) to be defined. Due to COVID-19 restrictions, the expert judgement per se and results analysis were conducted remotely through video-conferences from February to April 2020.

\subsection{Habitability Pillars}

The HPs were identified through the literature review, including peer-reviewed scientific papers and recent IPCC reports. This process highlighted that (1) availability of sufficient and safe land (Land); (2) supply of safe freshwater, especially from local sources (Freshwater supply); (3) supply of nutritious food from local and/or imported sources (Food supply); (4) access to safe settlements and infrastructure that sustains freedoms and opportunities such as for trade, healthcare and education (Settlements and infrastructure); and (5) access to sustainable economic activities (Economic activities) are all key to atoll habitability. These five HPs are under threat from climate change on atolls (Nurse et al., 2014, Table 29-4, p. 1635), with detrimental impacts, especially on well-being and health. These latter two components of habitability were not explicitly included in this study as HPs because they are mainly indirect outcomes of climate-driven changes to HPs. Impacts on wellbeing essentially arise from impacts on livelihoods, services and landscapes. Although climate change can have a direct impact on health (e.g. loss of lives from extreme events), most consequences for health are expected to be indirect, e.g. through increased water and food insecurity (Lovell, 2011).

\subsubsection{Availability of sufficient and safe land}

A complex combination of physical and ecological factors determines whether an atoll island is habitable or not. These factors include: island size and the extent of safe and utilizable land area (Spennemann, 1996; Weisler, 1999); island positional stability (Webb and Kench, 2010; Aslam and Kench, 2017); elevation of shoreline and interior, determining susceptibility to wave-driven flooding (Woodroffe, 2008; Owen et al., 2016); island shape and geomorphic components, which influence resistance to storms (Spennemann, 2009; Ford and Kench, 2014; Kumar et al., 2018); sediment composition, which influences groundwater resources and agroforestry potential; and the nature and extent of vegetation cover (Duvat et al., 2017a; Duvat et al., 2020a). Physical processes underpinning these attributes result from the interplay of a number of factors that vary across and within ocean basins (McLean and Kench, 2015). They include seasonal wave regimes (Morgan and Kench, 2014; Kench et al., 2017), exposure to high energy events such as storms and tsunami (Scoffin, 1993; Kench et al., 2006; Hoeke et al., 2013; Ford and Kench, 2014, 2016; Duvat et al., 2017a, 2017b), sea-level change (Perry et al., 2013; Kench et al., 2014), reef growth and related sediment supply and trapping by mangrove, seagrass and island vegetation (Perry et al., 2011; Krauss et al., 2014).

\subsubsection{Supply of safe freshwater, especially from local sources}


The contemporary resilience of atoll populations partly lies in their ability to exploit diverse water sources: rainwater harvesting, shallow fresh groundwater lenses (FGLs), desalinated water, imported water and, in extremis, coconuts (Foale, 2003; Falkland and White, 2020). Access to freshwater remains highly climate-dependent, as shown for example during the severe La Niña drought in 2011 across the southwestern Pacific (Lorrey and Renwick, 2011; Kuleshov et al., 2014) that led to freshwater shortages and national emergencies. Among water sources, FGLs play a major role in habitability, by providing adequate water to local communities and supporting agriculture and economic activities. FGLs result from a delicate balance between rapid rainwater recharge and continuing depletion due to evapotranspiration, discharge of groundwater to the surrounding ocean and lagoons, tidally-driven dispersive mixing with underlying seawater and groundwater pumping. Salinity gradients through FGLs depend on island area; sediment composition; recharge, discharge and pumping rates; tidal mixing; and method(s) of groundwater extraction (White and Falkland, 2010). Islands reliant on rainwater harvesting, either because their geomorphology and size do not support a viable FGL or because pollution or over-extraction has made their FGLs unusable (Falkland and White, 2020), are most at risk of supply failure. For some households on these islands, as little as 10 days without rain can lead to water supply failure (Quigley et al., 2016). At the other extreme, during high rainfalls, rainwater harvesting systems and ponded water increase risks of water-borne diseases (WHO, 2015).

\subsubsection{Supply of nutritious food from local and/or imported sources}

Achieving autonomous food security has always been a challenge on atolls because of limited land area and soil quality and high dependency on marine resources, both of which are climate-sensitive. Ad hoc and unplanned terrestrial food production (typically breadfruit, banana patches, coconut and others) remains common, including on many urban islands (e.g. Funafuti, Tuvalu; Tokelau; South Tarawa, Kiribati), and is key to people's diet. In addition, governments and development agencies support integrated farming practices and invest in soil management. Yet urbanization and human population growth have reduced land availability for locally-produced fruit and vegetables (Thaman, 1995; Connell, 2014; Campbell, 2015; Connell, 2020). Food imports (especially rice, canned meat, sugary drinks and snacks) have therefore become commonplace in both urban and rural islands (Campbell, 2020), inducing a 'nutrition transition' to cheaper, energy-dense, nutrient-poor foods (Hughes and Lawrence, 2005; Thow et al., 2010; Sievert et al., 2019), with a concomitant increase in risk of diet-related noncommunicable diseases. Climate change is poised to adversely affect food systems through disruptions in the ability of countries to import and distribute food, and of households to purchase food, with the potential to magnify food and nutrition insecurity (Savage et al., 2020).

Atoll communities have traditionally exhibited a significant dependence on fish for dietary protein and other essential micronutrients (Charlton et al., 2016). For example, average national fish consumption in Kiribati, Marshall Islands, Tuvalu and Tokelau is five times greater than in the high islands of Melanesia (SM2.1a). Rapid population growth and over-fishing are already reducing levels of per capita fish consumption, with consequences for human health (Golden et al., 2016; Hicks et al., 2019). There is an emerging gap in fish supply for urban atoll dwellers (Bell et al., 2011), exacerbated by the damage to proximal coral reef and seagrass habitats (SM2.2) and overexploitation of coastal fish stocks (McClanahan et al., 2011; Sale et al., 2014; MacNeil et al., 2015). Climate-related declines in fish abundance and associated catches are likely to further amplify existing declines in the nutritional adequacy of diets (Golden et al., 2016). Threats to fish supply are occurring despite availability of more than enough tuna and tuna-like species within the Exclusive Economic Zones (EEZs) of atoll nations to satisfy domestic demand (Bell et al., 2015). 


\subsubsection{Access to safe settlements and infrastructure that sustains freedoms and opportunities}

Owing to the comparatively small size and low elevation of atoll islands, settlements and infrastructure are all coastal in character and therefore more exposed to climate-driven damage than many of their higher island counterparts (Kumar and Taylor, 2015). Risk to settlements is driven by context-specific combinations of climate-related hazards (SLR and waves), the degree of degradation of surrounding ecosystems, and the distance to the shoreline and elevation of buildings and infrastructure. Critical infrastructure for island habitability includes those that are key to the functioning of the island internally (e.g. roads, fishing harbors, power and desalination plants, hydrocarbon reserves, administrative buildings and services) and the ones used for connection with other islands, atolls and countries (e.g. commercial and cruise harbors, regional and international airports, causeways and bridges connecting islands).

\subsubsection{Access to sustainable economic activities}

Besides declining copra production (Connell, 2014), atolls largely depend on tourism, fisheries, official development assistance (ODA) and remittances for income generation. Most atoll states also have an extraordinary economic dependence on industrial tuna fishing. The Western and Central Pacific Ocean and Indian Ocean are the world's first and second largest tuna production areas, providing 55 and 15\% of global tuna catch respectively (Pew, 2016; Lecomte et al., 2017). The economies of atoll nations such as Kiribati, Tuvalu, Marshall Islands and Tokelau therefore have a high dependence on fishing license fees, deriving the majority of their government revenue in this way (SPC, 2019; Lam et al., 2020). Tourism represents a unique opportunity because small and dispersed land areas and remoteness from markets can be attractive in a niche tourism context (Cagua et al., 2014; Jiang and DeLacy, 2014; Zimmerhackel et al., 2019). Many atoll nations also rely on ODA to bolster economic development (representing ca. 15\% of Gross National Income in Kiribati; Dornan and Pryke, 2017), and remittances from migrants working overseas largely contribute to national incomes (14, 11 and $10 \%$ of GDP respectively in the Marshall Islands, Tuvalu and Kiribati). Other activities include aquarium fisheries (e.g. Marshall Islands, French Polynesia and Kiribati), pearl farming (e.g. French Polynesia and Cook Islands), and subsidized copra production (e.g. Kiribati and French Polynesia). These economic activities are highly sensitive to both climate shocks (e.g. changes in temperatures, flooding) and ecosystem health, making the economy of atolls disproportionally vulnerable to climate change impacts.

\subsection{Regions and islands of interest}

This study focuses on the two regions in which $96 \%$ of the world's atolls and the most populated atolls are located, namely the Indian (56 atolls, according to Goldberg, 2016) and Pacific Oceans (367 atolls; Goldberg, 2016). Specifically, we assess the exposure of atolls to climate stressors in three distinct sub-regions, the Central Indian Ocean, Central Pacific and Western Pacific (section 2.3). We also assess climate risk to habitability for four contrasting islands in the Central Indian Ocean and Western Pacific (listed below; see SM5 for detailed description). These islands are representative of the diversity of atoll contexts and, with the exception of Nolhivaranfaru, Maldives, are documented and well-known by the authors. We considered urban and rural islands to highlight variable exposure and vulnerability conditions to climate stressors (Duvat et al., 2017). Urban case studies are illustrated by Male', North Kaafu Atoll, Maldives, which is a 'fortified' island, and Fogafale, Funafuti Atoll, Tuvalu, which is flood-prone and has limited coastal protection. Rural case studies include Tabiteuea, North Tarawa, Kiribati, bordering the South Tarawa Urban District, and the remote island of Nolhivaranfaru, Haa Alifu-Noonu Atoll, Maldives.

\subsection{Climate stressors}


The scientific literature, including recently released IPCC reports (IPCC 2018, 2019) and peerreviewed papers, allowed identification of the major climate stressors affecting HPs considered in this study. These include slow onset climate changes (in atmospheric temperatures and rainfall patterns), slow onset ocean changes (in sea level, sea surface temperatures (SST) and ocean acidification), and changes in extreme events, especially tropical cyclones, El Niño/La Niña events, marine heat waves and distance-source waves. Using these stressors, we generated CMIP5 projections to estimate the exposure of each abovementioned sub-region to climate change-related risk (section 3.1, SM3). These projections also served as starting points to assess climate risk to island habitability (section 4).

CMIP5 data (Taylor et al., 2012) show how the magnitudes of SLR, SST, rainfall, ocean pH and aragonite saturation, ENSO and tropical cyclones will influence the five HPs. All vary (1) under two contrasting greenhouse gas (GHG) emission scenarios, i.e. RCP2.6 representing a drastic mitigation scenario and RCP8.5 assuming continued acceleration of GHGs emissions; and (2) at two time horizons, 2050 and 2090. The abovementioned stressors were aggregated into a cumulative exposure index for each RCP scenario, timespan and sub-region, following a 3-step approach: selection of the mean, minimum and maximum value for each parameter (SM3.1) from future projections, and regional baseline values; development of a scoring system by sub-region (SM_File 2_SM3); and establishment of index scores (SM3.2).

\subsection{Risk assessment protocol}

\subsubsection{Expert judgment and scoring system}

The expert judgment-based assessment of the climate risk posed to habitability relied on an extensive literature review (including especially case study papers), available datasets, and the authors' own expertise. It followed a 6-step approach (Fig. 2; SM4). Briefly, the protocol consisted of defining a set of prominent criteria contributing to risk for each HP and in each of the four case studies considered (step 1); as well as a scoring system to assess the additional climate risks to each criterion under RCP2.6 and RCP8.5, and for 2050 and 2090 (step 2, SM7). Six risk levels were considered: undetectable, very low, low, moderate, high, very high, (Table SM4b). For each HP, between two and four of the authors conducted a separate assessment for the criteria and then convened (virtually) to discuss their respective scores and agree on a final score and articulate underlying rationales. Confidence levels were attributed to each score (step 3). The aggregation of scores for each HP (step 4) allowed identification of climate risk to island habitability as a whole (step 5). The results were then translated into a color scale to develop synthesis figures of climate risk to habitability across HPs and case studies (step 6; Figs. 5 and 6). 
14 criteria

- Land (HP1): coastal erosion, marine flooding

- Freshwater supply (HP2): fresh groundwater salinization,

decrease in rainwater harvesting, decrease in

desalination

- Food supply (HP3): reduced reef fish production

redistribution of tuna, reduced crops and livestock production

- Risk criteria identification for each Habitability Pillar (HP)

- Design of the assessment method

Settlements and infrastructure (HP4): loss of settlements, critical infrastructure and transport connectivity

- Economic activities (HP5): reduction in tuna fisheries

revenues, tourism revenue, and other revenue streams

- Scoring system, from 0 ("undetectable"

Scoring system, from 0 ("undetectable"
additional risk from climate stressors) to 5 (very high contribution)

- Under RCP2.6 and RCP8.5

- In 2050 and 2090

- Application to the 4 case studies

- Expert judgment (set of 2-4 authors), based on case study-oriented papers, available datasets review of the general literature, and authors' own expertise

Step 3

- Confidence level, from Low (1) to Medium (2) and High (3)

- For each criteria score

- Expert judgment

Step 4

- Aggregation of criteria scores for each Habitability Pillar

- Weighting of criteria scores for each Habitability Pillar

\section{Step 5}

- Combination of aggregated scores for each

Habitability Pillar

- Weighting of HP1 aggregated score (x2) compared to the other HP aggregated scores (x1)

- Final analysis across HPs

- Final analysis across case studies

\section{Step 6}

- Translation of HP aggregated risk levels into a color graduation

- Synthesis figure of risk to habitability across HPS

- Synthesis figure of risk to habitability across case studies

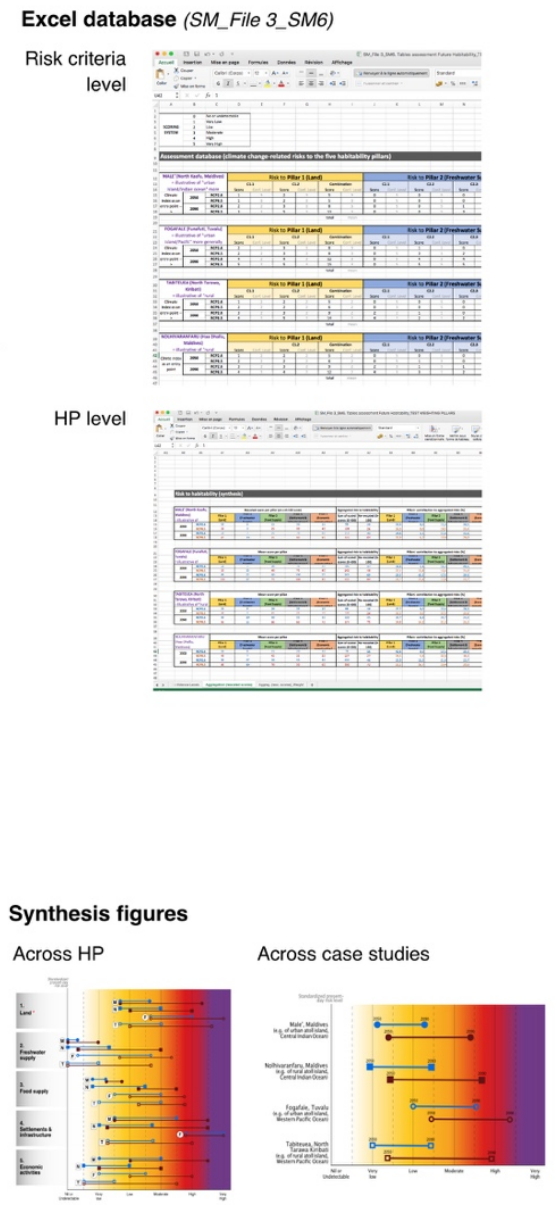

Figure 2. Assessment protocol used in this study.

See SM4 for further details.

\subsubsection{Adaptation assumptions}

We assume that, over the timeframe of analysis, future adaptation responses in urban and rural islands will remain similar in nature and magnitude to currently observed responses. Two main reasons support this argument. First, because atoll communities have adapted to climate stress for centuries to millennia (Nunn, 2007), and still implement climate risk reduction actions, we excluded the "no adaptation" scenario (section 3.2). Second, due to a lack of precise and empirically-based information on the extent and nature of adaptation limits in atolls (Roy et al., 2018; Mechler et al., 2020), especially across the diversity of case study settings chosen, we did not consider a "high adaptation" scenario involving more transformational changes. We therefore assume the 
continuation of the current level of adaptation measures, i.e. moderate adaptation, which is considered feasible and helps the understanding of risk under a non-transformational adaptation pathway. This adaptation scenario considers mechanisms already implemented on the ground, including water desalination (to counter water stress), remittances from islanders working abroad, food imports (which help compensate for locally-produced food decline), hard protection to contain coastal erosion and flooding, and, in the Pacific Ocean, emerging tuna fishing governance arrangements between countries. In the absence of local-scale modelling studies, our adaptation assumptions do not consider exogenous parameters such as, in the tourism sector for example, the effect of climate policy on international transportation or the ability for local operators to adapt to changing circumstances, including COVID-19 impacts.

\section{CURRENT AND FUTURE CLIMATE THREATS TO HABITABILITY PILLARS}

\subsection{Climate projections}

The mean rate of global SLR for 2006-2015 was $3.6 \mathrm{~mm} \mathrm{yr}^{-1}$ (IPCC, 2019). Under RCP2.6, mean rates of 4.5 and $4.8 \mathrm{~mm} \mathrm{yr}^{-1}$ are projected for 2050 for the Central Indian and Western Pacific Oceans respectively, and 4.6 and $5.1 \mathrm{~mm} \mathrm{yr}^{-1}$ for 2090 (Fig. 3, SM3). Under RCP 8.5, mean rates are 7.6 and $8.2 \mathrm{~mm} \mathrm{yr}^{-1}$ for 2050, and 15.0 and $15.4 \mathrm{~mm} \mathrm{yr}^{-1}$ for 2090. SLR is projected to increase water depths above reefs surrounding many islands (Perry et al., 2018), meaning that higher waves will reach shorelines, amplifying flooding frequency and rates of shoreline erosion.

For SST, there is little projected change between 2050 and 2090 under RCP2.6 (Fig. 3). Under RCP8.5, projected SST increases from 2050 to 2090 by around $1.5^{\circ} \mathrm{C}$, likely increasing the frequency and magnitude of marine heat waves (Frölicher et al., 2018; Dalton et al., 2020) and pushing mean SST levels above local coral bleaching thresholds more frequently in all regions, except the Central Pacific (Fig. 3). This is consistent with projections of the onset of annual bleaching by ca. 2040 in Kiribati, Marshall Islands, Tokelau and Tuvalu in the Pacific Ocean, and in the Maldives (van Hooidonk et al., 2016).

Rainfall projections indicate overall positive changes within $\pm 10^{\circ}$ of the equatorial Pacific and northern Indian Oceans (Fig. 3). While under RCP2.6 small increases are projected for 2050 and 2090, larger (6\% or more) positive increases are projected under RCP8.5, especially for the Western Pacific. No decrease in annual rainfall is projected for any of the emission scenarios considered. Mean rainfall change is therefore regarded as a minor driver in this assessment. In contrast, projections suggest that the frequency of intense droughts may double over the course of the $21^{\text {st }}$ century (IPCC, 2019).

IPCC (2019) also finds that the frequency of extreme ENSO events will double under both RCP2.6 and RCP8.5 in the 21st century, with the average frequency increasing from once every two decades to once per decade (Cai et al., 2014a; Cai et al., 2015; Cai et al., 2018). Extreme Indian Ocean Dipole (IOD) events are also projected to increase in frequency (Cai et al., 2014b).

In non-equatorial atoll regions, the proportion of high-intensity tropical cyclones is projected to increase whereas the total number of cyclones is expected to remain the same or decrease slightly (Knutson et al., 2019; Murakami et al., 2020). Analysis of cyclones globally over the past 39 years has shown a significant increase in intensity globally but in the northern Indian Ocean, equatorial and southern Pacific Ocean changes in intensity have not been significant $(p>0.1)$. 
Increased wind speeds in the Southern Ocean and tropical Eastern Pacific are projected to increase wave heights (Morim et al., 2018; 2019) and thus raise the potential for long period swell waves to impact distant atoll islands.

Regarding ocean acidification, under $\mathrm{RCP} 2.6 \mathrm{pH}$ and aragonite saturation rate are projected to continue to fall until 2050 in the three sub-regions and revert to slightly higher values between 2050 and 2090 (Fig. 3). Under RCP8.5, both pH and the aragonite saturation rate $\left(\Omega_{\mathrm{a}}\right)$ continue to fall between 2050 and 2090, reaching by $2090 \Omega_{\text {a }}$ values of $<2.5$, below the typical values found in coral reef waters (Kleypas et al., 1999).

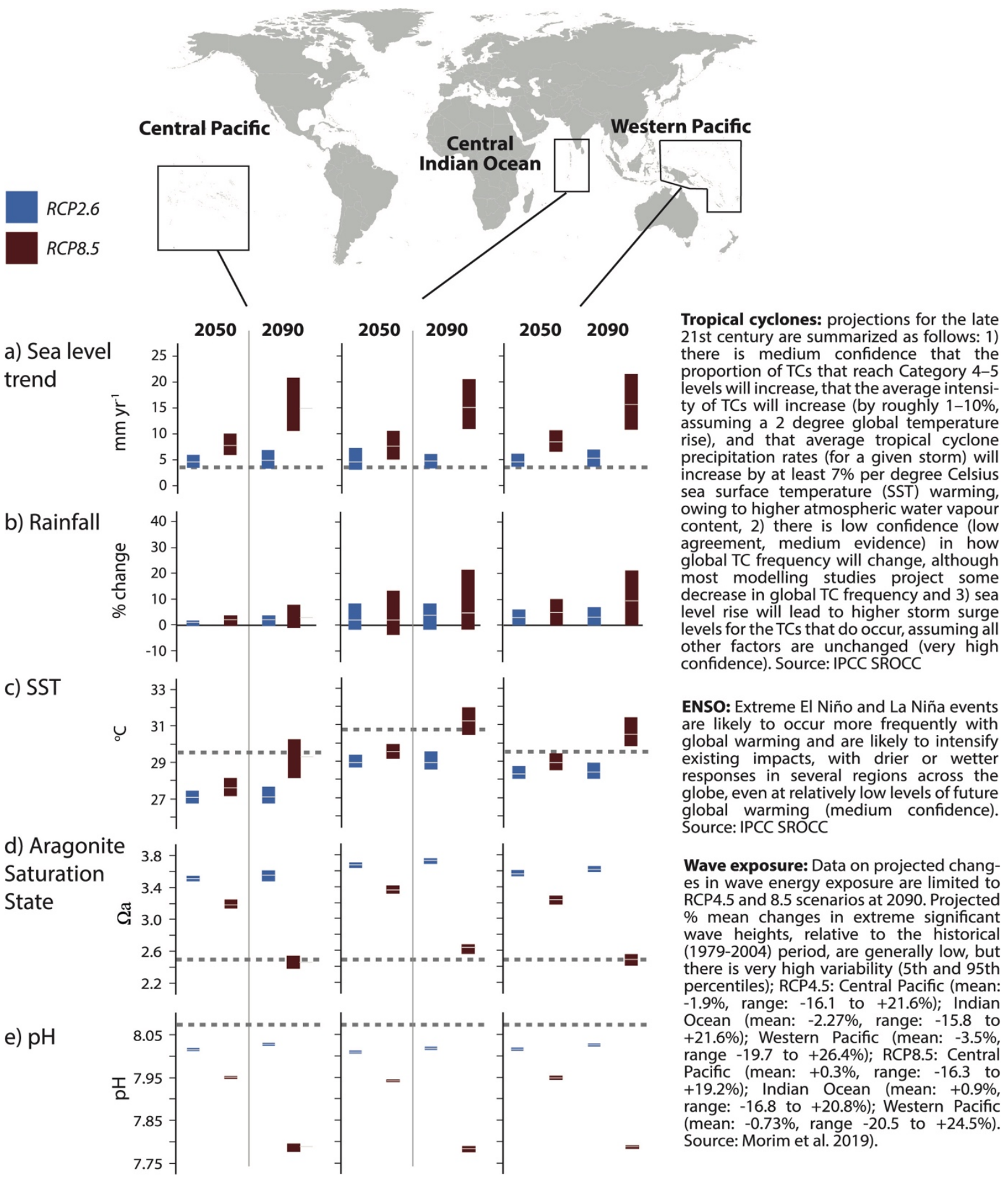

Figure 3. Projected changes in relevant climate change-driven ocean and atmospheric parameters within different atoll regions for each emissions scenario in 2050 and 2090. 
Plots a-e show upper, mean and lower limit projected changes in each parameter under RCP2.6 and RCP8.5 in 2050 and 2090 for each atoll sub-region (see also SM3.1). The threshold levels (grey bars) denote the following: for sea level trend, the mean rate of global sea-level rise (3.6 $\left.\mathrm{mm} \mathrm{yr}^{-1}\right)$ between 2006-2015 (IPCC, 2019); for SST trends, regional bleaching thresholds (from NOAA Coral Reef Watch, 2001-2020 time series data); for Aragonite Saturation State trends, the threshold below which conditions for tropical reef-building corals are deemed to be "extremely marginal" (Guinotte et al., 2003); for surface $\mathrm{pH}$, the mean surface $\mathrm{pH}$ in tropical regions during the period 1980-2000 (IPCC, 2014, Fig. 30.7).

These projections provide a basis for assessing the cumulative exposure of each sub-region (Fig. 4; SM3.2). Our assessment suggests low overall levels of increased exposure under RCP2.6 but increased SST stress in the Central Indian Ocean, with a significantly increased cumulative exposure to climate stressors to at least 2090 under RCP8.5. Under RCP8.5, changing ocean chemistry conditions will be the most sustained drivers of this increased exposure. The combination of risks generated by SLR and changes in SST will become significant between 2050 and 2090 and will almost certainly be further exacerbated in most regions by increased cyclone intensity, and in all regions by increased frequency of intense ENSO and IOD events (Figs. 3 and 4 and SM3).

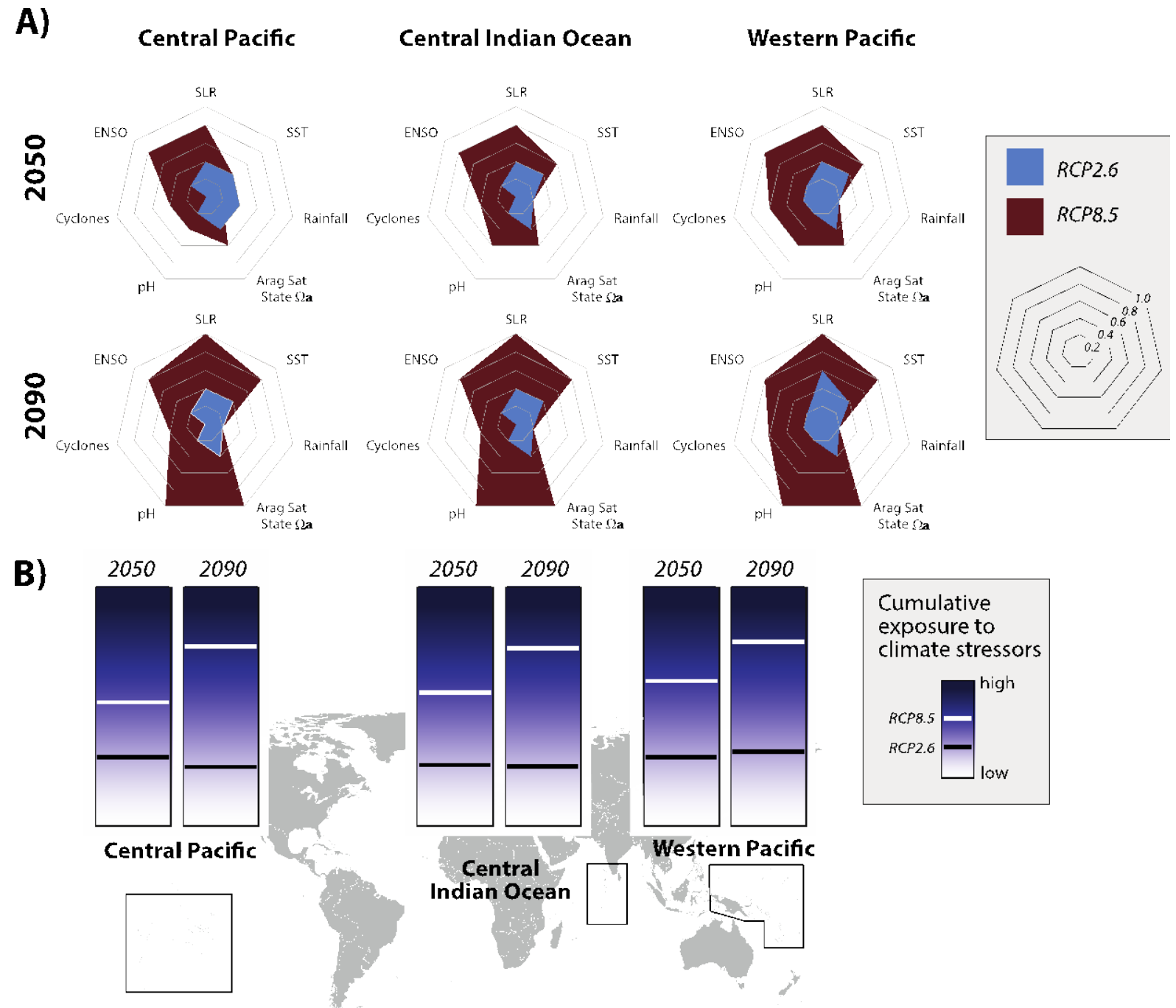

Figure 4. Cumulative climate change threats and related exposure of atoll regions, for two emission scenarios in 2050 and 2090, based on mean projected rates of change.

SM3.1 provides the full details. Panel A illustrates the cumulative climate and climate-related ocean threats ( $h i g h=1.0$, low $=0.0$ ) to atoll habitability for each of the three delineated atoll regions. Panel B shows resultant cumulative exposure index for each RCP scenario and atoll region. The index is described in SM3.2. The color graduation represents increasing exposure levels from low (white to light blue) to high (deep blue). 


\subsection{Literature-based perspective on threats to Habitability Pillars}

\subsubsection{Land (HP1)}

A review of shoreline change of 709 Indo-Pacific atoll islands over the past 3-5 decades found no widespread trend in land area change for larger (>10 ha) habitable islands (Duvat, 2019), indicating shoreline resilience in the face of recent climate-driven changes. Nevertheless, the low elevation and permeable structure of all islands expose them to overtopping-induced flooding, marginal breaching and/or saltwater intrusion (Hoeke et al., 2013; Canavesio, 2019; Wadey et al., 2017). The likelihood of island flooding associated with extreme sea levels arises from a combination of factors (regional sea-level, storm frequency variations, wave climate changes) and operates over multiple spatialtemporal scales (Walsh et al., 2012; Chand et al., 2013). Major contributors are distant ocean waves that reach the shorelines of atolls, resulting in enhanced wave setup and runup, overtopping of berms and protection structures, and inundation of island interiors.

Direct impacts of climate-ocean changes will result from extreme wave energy (from tropical cyclones and distant storms) altering shorelines, whilst indirect effects will come from changes in the ecological make-up and structural complexity of reefs (Perry et al., 2011; Quataert et al., 2015; Harris et al., 2018), and in the extent and health of mangroves (Schuerch et al., 2018) and seagrasses, as well as terrestrial vegetation (Hernandez-Delgado, 2015). Changes affecting reefs will limit their capacity to keep pace with SLR (Perry et al., 2018), attenuate wave energy, and contribute to sediment supply to islands. Increased frequency and intensity of coral bleaching events and increased ocean acidification will be the most immediate drivers of such changes (Frölicher et al., 2018; Perry et al., 2018). Precisely how the former will impact reef sediment generation is unclear, although short-term pulses of enhanced sediment generation have been observed after bleaching events (Kayanne et al., 2016; Perry et al., 2020). Likewise, the implications of pH and aragonite declines on sediment generation rates are poorly known. Despite these uncertainties, under RCP8.5 from 2050, the accumulation of threats to reefs will severely exacerbate island flooding, as a result of SLR and reef erosion, leading to island destabilization through increased wave impact on shorelines and a net reduction in sediment supply to islands (Beetham et al., 2017; Shope et al., 2017; Storlazzi et al., 2018; Shope and Storlazzi, 2019; East et al., 2020). Decreased sediment supply, from both external minerogenic and in situ organic sources, will compromise the ability of mangrove substrates to keep pace with SLR (Lovelock et al., 2015).

In densely settled areas, human constructions will increasingly compromise the natural ability of island shorelines to vertically adjust to SLR by altering reef productivity, obstructing alongshore and cross-shore sediment transport pathways, and reducing the coastal accommodation space available for landform adjustment, including opportunities for the landward migration of coastal habitats (McLean and Kench, 2015; Schuerch et al., 2018; Duvat and Magnan, 2019). If pathways of in situ adaptation continue to be followed, this will make atolls increasingly dependent on protection structures, aimed at limiting shoreline erosion and flooding (Naylor, 2015; Wadey et al., 2017; Hinkel et al., 2018), and possibly island raising (e.g. Hulhumale', Maldives; Brown et al., 2020).

\subsubsection{Freshwater supply (HP2)}

Mean annual and wet-season rainfall are projected to increase across the equatorial Eastern and Central Pacific in the 20-year periods centered on 2050 and 2090 (relative to 1986-2005) but there is little change expected further from the equator (ABoM and CSIRO, 2014) (Figs. 3 and 4). The frequency and intensity of extreme rainfall events are projected to increase across the Western and Central Pacific, but their magnitude is uncertain (ABoM and CSIRO, 2014). Projected increases in frequency of the 1-in-20 year daily rainfall (baseline 1985-2005) for RCP2.6 and RCP8.5 are location- 
specific, with doubling frequency for RCP2.6 (ABoM and CSIRO, 2014). The low confidence in the magnitudes of these projected changes hinders the quantification of their impacts on freshwater supply, particularly as there are no comparable projections for evapotranspiration (Falkland and White, 2020). Qualitatively, these intensifications suggest increased local flooding as groundwater rises to the surface, increased pollution of FGLs (Falkland and White, 2020) and polluted discharge onto surrounding reefs (Graham et al., 2018), with cascading negative impacts on shoreline protection, sediment supply, food production and health (White et al., 2007; WHO, 2015; UNICEF and WHO, 2019).

Increased frequency (and intensity under RCP8.5) of major ENSO and IOD events may challenge water security, especially for rainwater harvesting on urban atolls. Modelling shows that, when there is no land area loss, the store of freshwater increases slightly with SLR up to $0.4 \mathrm{~m}$, as groundwater moves up from karst limestone basements into overlying unconsolidated Holocene sediments (Alam and Falkland, 1997; Galvis-Rodriguez et al., 2017). This magnitude of SLR is comparable to sea-level differences experienced during major ENSO events (Widlansky et al., 2017) and to SLR projected under RCP2.6 to 2090 (ABoM and CSIRO, 2014). With SLR rates of $\sim 15 \mathrm{~mm} \mathrm{yr-}{ }^{1}$ projected for RCP8.5 at 2090 (ABoM and CSIRO, 2014), land area loss could reduce groundwater availability by over $70 \%$ by 2090 (e.g. South Tarawa; Alam and Falkland, 1997). Likewise, in the Maldives, islands narrower than $200 \mathrm{~m}$ are expected to experience drastic reductions of their FGLs from the combined effects of variable rainfall patterns and SLR (Deng and Bailey, 2017). More frequent island overtopping will cause salinization of FGLs (Burns, 2002; Storlazzi et al., 2018; Hughes et al., 2020). Experiences in the Pacific and Indian Oceans and overwash modelling suggest that FGL recovery takes between one to five years (Chui and Terry, 2015; Bailey and Jensen, 2014; Bailey, 2015). The implication is that alternative sources of water will be needed during periods of FGL recovery.

Since projected increases in annual rainfall are relatively small, future freshwater security in atolls will depend significantly on changes in the frequency and intensity of ENSO and IOD events, the intensity of cyclones and accompanying storm surges (Chui and Terry, 2013), as well as the ability of islands to build vertically to adjust to SLR (Tuck et al., 2019). However, at least until 2030, nonclimate-change factors, including increasing freshwater demand, urbanization, water pollution, governance and management failures, are expected to pose greater threats to freshwater security than climate change (Falkland, 2011).

\subsubsection{Food supply (HP3)}

Rapid population growth (3.2.4), urbanization and over-fishing of coastal stocks will continue compounding food security challenges by reducing land availability for agriculture and levels of per capita fish consumption (SM2.3). These challenges will be exacerbated by projected declines in fish abundance and catches in relevant sub-regions (Asch et al., 2018, Bell et al., 2018a). For reef fisheries, recent coral bleaching and mortality (e.g. Hughes et al., 2018), and resultant reef structural collapse, have led to declines in fish commonly targeted by these fisheries (Robinson et al., 2019a).

Minimizing the gap in fish supply is achievable through adequate protection of coral reef and seagrass habitats (Brodie et al., 2020), improved management of coastal fish stocks (Bell et al., 2018a), increases in the catch of tuna and tuna-like species from nearshore waters (e.g. Maldives; Yadav et al., 2019), as well as greater access afforded to offshore tuna and tuna-like species for domestic consumption (Bell et al., 2015; FFA \& SPC, 2015). For Pacific atolls, expanding the use of nearshore fish aggregating devices (FADs) would increase supplies of tuna for local food security (Bell et al., 2018a) (SM2.4). Filling the gap in fish supply is all the more crucial that climate-driven 
changes to soil moisture and salinization levels, rainfall and land area will increasingly constrain food production on atolls (Taylor et al., 2016; Barkey and Bailey, 2017).

Ocean warming and acidification are expected to significantly reduce live coral cover (HoeghGuldberg et al., 2011). Although increased $\mathrm{CO}_{2}$ concentrations should promote growth of seagrasses, on balance, climate change is likely to continue to reduce this important fish habitat within atoll lagoons (Waycott et al., 2011) (SM2.5). Together, these effects and the direct impact of ocean warming on coastal fish species are projected to reduce coastal fish stocks by $20-50 \%$ by 2050 (Pratchett et al., 2011, 2014; Asch et al., 2018). Degraded coral reefs may, however, support higher catches of fast-growing herbivorous fish species (Pratchett et al., 2011), helping offset predicted declines in productivity of other coastal fish species (Robinson et al., 2019b) (SM2.6). Climate change risks to coastal fish productivity, exacerbated by inadequate management, are of particular concern for rural communities (Thow and Snowdon, 2010) (SM2.1.b, SM2.3).

Climate change will also alter the distribution of tuna in both the Pacific and Indian Oceans (Bell et al., 2016; 2018b). This is unlikely to affect plans to assist communities to catch more tuna around FADs because, even under RCP8.5 in 2050, a large biomass of tuna is still expected to exist within atoll nations' EEZs (Bell et al., 2018a). Projected decreases in tuna biomass in the Marshall Islands, Tokelau and Tuvalu (SPC, 2019) will necessitate allocation of a higher proportion of their (reduced) tuna resources to domestic consumption.

\subsubsection{Settlements and infrastructure (HP4)}

In 2017, 676,000 people were living in the Maldives, Kiribati, Marshall Islands, Tuamotu-Gambier, Tuvalu, FSM and Tokelau (SM1). Together, these archipelagoes have experienced a $68 \%$ population increase since the mid-1980s, with the main growth observed in the Maldives and Kiribati (SM1a). Urban/capital islands are home to most people, as a consequence of better services and infrastructure, higher life expectancy and rural exodus (Yamano et al., 2007; Duvat et al., 2013; Speelman et al., 2017). For example, in 2017, 49\% of the 114,160 I-Kiribati were living in South Tarawa ( $<2 \%$ of the country's land area), and in 2016, 32\% of the 402,000 Maldivians were concentrated on Male' ( $<1 \%$ of the country's land area). This resulted in high population densities ranging from 1,354 persons $\mathrm{km}^{-2}$ on Rangiroa (Tuamotu) to 65,697 persons $\mathrm{km}^{-2}$ on Male'.

On these islands, limited available land area forces the settlement of risk-prone areas, further increasing population exposure to environmental hazards (Duvat et al., 2017c). For atoll nations as a whole, Kumar and Taylor (2015) estimated that $90 \%$ of built assets are located $<100 \mathrm{~m}$ from the shoreline. On the capital islands of Rangiroa and Funafuti, land constraints have led to swamp reclamation for construction purposes, amplifying population exposure to flooding (Yamano et al., 2007; Magnan et al., 2019; Duvat et al., 2020b). The expansion of Male' through land reclamation ( $+67 \%$ since the 1970 s, mostly $<1 \mathrm{~m}$ above Mean Sea Level) has also increased the exposure of people and urban assets to sea-level extremes (Naylor, 2015).

About $59 \%$ and $61 \%$ of the populations of Tuvalu and the Marshall Islands respectively currently live on land below annual flood levels. These proportions will increase by about 10 and $27 \%$ respectively in the case of a $1 \mathrm{~m}$ SLR by 2100 (Kulp and Strauss, 2019). On Ebeye, Kwajalein Atoll, Marshall Islands, the population annually affected by flooding and erosion will increase from 5,000 persons ( $>50 \%$ of its population) to $8,800(10,800)$ under RCP2.6 (RCP8.5) by 2100; and Expected Annual Damages (EAD) to buildings and infrastructure are projected to increase 2.4 to 3.8 times by 2100 (Giardino et al., 2018). 
Estimating future threats to settlements and infrastructure on atolls for the $21^{\text {st }}$ century is challenging because of a lack of knowledge of the influence of human drivers of exposure and vulnerability. In Tuvalu, migration flows have the potential to slow population growth by the midcentury, from 3700 additional inhabitants if no out-migration occurs against 320 inhabitants with substantial emigration (Milan et al., 2016). Future risk to settlements and infrastructure will also depend on the effectiveness and sustainability of responses (Nunn and Kumar, 2018). On Ebeye, hard defenses have the potential to reduce end-century flooding/erosion-induced EAD by $30 \%$, and the annually affected population by $40 \%$ (Giardino et al., 2018). Likewise, building seawalls $0.5,1.0$ and $1.5 \mathrm{~m}$ high could delay flooding for $0.2,0.4$ and $0.6 \mathrm{~m}$ of SLR respectively on the raised island of Hulhumale', Maldives, (Brown et al., 2020). Future threats to settlements and infrastructure will also depend on accommodation efforts, especially floor raising (e.g. Tuamotu; Magnan et al., 2019).

\subsubsection{Economic activities (HP5)}

In 2016, fisheries revenues related to license fees contributed $60-98 \%$ of all (non-aid) government revenue of Kiribati, Tuvalu, Marshall Islands and Tokelau (FFA, 2017). Overall, climate-driven redistribution of tuna is expected to have greater effects on the economies of Pacific Ocean than Indian Ocean atolls (Bell et al., 2016, 2018a). Under RCP8.5 by 2050, tuna biomass in national waters is projected to decrease by $15 \%$ in the Marshall Islands and $9 \%$ in Tuvalu and Tokelau, and to increase by $18 \%$ in Kiribati (SPC, 2019). Proportional decreases and increases in tuna license revenue are expected to occur.

Together with other Pacific Island countries that are Parties to the Nauru Agreement (PNA), Kiribati, the Marshall Islands, Tokelau and Tuvalu have responded to climate variability and change through the 'vessel day scheme' (VDS), which enables the benefits of purse-seine fishing within their combined EEZs to be distributed equitably among them, regardless of where the fish are caught (Aqorau et al., 2018; Johnson et al., 2020). Nevertheless, under RCP8.5 by 2050, tuna biomass within the combined EEZs of PNA members is likely to decrease because conditions for tuna will become more favorable further east in high-seas areas (SPC, 2019). This will necessitate new management arrangements and could potentially set the stage for conflict between tuna-fishing nations (Pinsky et al., 2018).

Tourism grew in the Maldives between 1995 and 2017 from 315,000 international arrivals and US\$211 million in tourism receipts to 1.4 million and US\$2,742 million respectively. In 2017, tourism accounted for $23 \%$ of GDP and $32 \%$ of government revenue (Ministry of Tourism, 2018). While Pacific atoll nations are less likely to benefit from positive visitor projections (World Bank, 2017) due to less developed tourism assets, FSM, Marshall Islands, Kiribati and Tuvalu are well placed to capitalize on nature-based experiences (e.g. diving, sport-fishing). Atoll tourism is assumed to be as much at risk as in coastal areas elsewhere, where it relies on beach and marine activities (Klint et al., 2015; van der Veeken et al., 2015; Bindoff et al., 2019; Fauzel, 2019; Seetanah and Fauzel, 2019). SLR, warmer SSTs and extreme events are likely to affect tourism through damage to essential infrastructure (UNFCCC, 2005), loss of beaches and coral bleaching (Wielgus et al., 2002; Koike et al., 2014; Weatherdon et al., 2016).

ODA allocations to atoll nations have declined over the past decade (OECD, 2015). While commitments in climate finance to Small Island Developing States have been made, current climate finance models may not be appropriate or large enough to meet needs, and lack the required governance to effectively support resilience and promote sustainable development (Williams and McDuie-Ra, 2018). The role of remittances for increased household resilience, and to finance adaptation, could increase in importance if other income sources decline and externally-provided climate finance is insufficient (Bendandi and Pauw, 2016; Musa-Surugu et al., 2018; Nunn and 
Kumar, 2019). Remittances may also help limit rural exodus and international migration attributable to climate change (Damette and Gittard, 2017). However, falling remittances as a result of crises such as the current COVID-19 pandemic (IMF, 2020) may have profound and unforeseen economic impacts.

\section{ASSESSMENT OF CLIMATE RISK TO FUTURE HABITABILITY IN FOUR ATOLL ISLANDS}

\subsection{Risk by Habitability Pillar}

Risk to Land (HP1, SM7.1) includes permanent coastal erosion, and permanent and temporary marine flooding. This risk is estimated very low-to-low for all four islands in 2050 under RCP2.6, except for Fogafale which shows a low-to-moderate risk due to its high susceptibility to flooding (Fig. 5). By 2090 under RCP2.6, this risk increases to low-to-moderate for Male', moderate for Nolhivaranfaru and Tabiteuea, and high for Fogafale. While there is a relatively small difference in risk level between RCP2.6 and RCP8.5 in 2050, the risk to land increases substantially under RCP8.5 in 2090 compared to RCP2.6, and is high for Nolhivaranfaru, high-to-very high for Male' and Tabiteuea, and very high for Fogafale. This is due to sea-level projections diverging between low and high emission scenarios after 2050 only. Differences in risk level are generally small between rural islands, but high between urban islands. Male' exhibits lower risk than Fogafale, owing to its higher elevation and complete protection by engineered structures, while Fogafale is both extremely lowlying and mostly unprotected.

Risk to Freshwater supply (HP2, SM7.2) includes groundwater salinization/loss and decrease in rainwater harvesting and desalination. This risk is estimated as undetectable in 2050 under RCP2.6 for all islands, except for Fogafale where the predominant source of freshwater, rainwater harvesting, will likely be disrupted by increased cyclone-driven damage and drought frequency (Fig. 5). While risk remains undetectable-to-very low in Male' under all RCPs even in 2090 - because it mainly relies on desalination - it slightly increases under RCP2.6 in 2090 in Nolhivaranfaru and Tabiteauea (to very low-to-low and very low, respectively) and, more in Fogafale (to low-tomoderate). This increase is even more important under RCP8.5 in 2090 (moderate for Nolhivaranfaru; low-to-moderate for Tabiteuea; moderate-to-high for Fogafale). Fogafale exhibits the highest risk level because of its main reliance on rainwater harvesting which will be increasingly affected by droughts, cyclones, and flooding-induced damage over time. On rural islands, risk thus becomes significant under RCP8.5 in 2090.

Risk to Food supply (HP3, SM7.3) includes reduced reef fish production, redistribution of oceanic tuna and reduced production of crops and livestock. This risk is assessed as very low for all islands under RCP2.6 in 2050 (Fig. 5). Differences between islands are pronounced in 2090 under both RCP2.6 (slightly above very low-to-low for Male', low-to-moderate for Nolhivaranfaru, moderate for Fogafale and Tabiteuea) and RCP8.5 (from moderate to high, except for Male' where it remains very low-to-low). The lower risk level for Male' is due to the relatively low dependence of households on local food compared to imports; these are assumed to increase over time to compensate for decreasing tuna catches. The comparatively higher risk level for Fogafale results from the cumulative effects of decreased reef fish ( $60 \%$ of total catches in Tuvalu) and tuna catches, and a reduction in agricultural productivity and livestock due to marine flooding. In all cases, food imports are likely to increase to compensate for decreased local-to-national food production, especially in the second half of this century.

Risk to Settlements and infrastructure (HP4, SM7.4) includes loss of settlements, critical infrastructure and transport connectivity. Since this risk is strongly influenced by risk to Land, risk levels partly reflect those of Land, being very low to low under RCP2.6 in 2050, except for Fogafale (close to high); and low-to-moderate for Nolhivaranfaru and Tabiteuea, moderate-to-high for Male' and very for Fogafale under RCP2.6 in 2090 (Fig. 5). Mid- and end-century risk levels are thus higher 
in Fogafale compared to other settings, as a result of both the higher exposure of settlements and critical infrastructure to coastal risks (especially flooding) and the reduced extent and effectiveness of protection structures. In contrast, because it is protected by its encircling engineered structures, Male' exhibits very low-to-low risk under RCPs 2.6 and 8.5 respectively in 2050 . Since the effectiveness of coastal protection decreases over time under SLR and increased wave height (e.g. Giardino et al., 2018; Brown et al., 2020), risk to settlements and infrastructure increases to moderate-to-high and high-to-very high respectively under both RCP2.6 and RCP8.5 in 2090. Under RCP2.6 in 2090, risk levels are lower in rural islands compared to Male' because they exhibit lower exposure of settlements and infrastructure compared to urban settings.

Risk to Economic activities (HP5, SM7.5) includes declines in tuna fisheries revenues, tourism revenues (especially in the Maldives), and other revenue generating activities (e.g. aquaculture). This risk, which is highly influenced by risks to Land and Food supply, is at most very low and at most low under RCP2.6 and RCP8.5 in 2050 respectively, with higher levels on urban islands where these activities are more common (Fig. 5). Consequently, end-of-century risk to economic activities under RCP8.5 reaches much higher levels for urban islands (high for Fogafale and high-to-very high for Male') compared to rural islands (moderate for Nolhivaranfaru and moderate-to-high for Tabiteauea).

These findings firstly highlight that Freshwater supply (HP2), where use of desalination is always an option, is less threatened by climate change than the other HPs. Conversely, Land (HP1) is at high risk from climate change impacts. This risk cascades down to land-based Food supply (HP3), Settlements and infrastructure (HP4), and land-based Economic activities (HP5). Second, risks are commonly very-low-to-low (in 2050) to moderate (in 2090) under RCP2.6 for most HPs. Risks increase significantly between 2050 and 2090 under RCP8.5, from around low classifications to moderate or very high risk for most HPs and islands. Third, even the best protected urban island (Male'), with estimates of undetectable to at most moderate risk under RCP 2.6 both in 2050 and 2090, faces high-to-very high risk under RCP8.5 in 2090 for Land (HP1), Settlements and infrastructure (HP4), as well as Economic activities (HP5). 


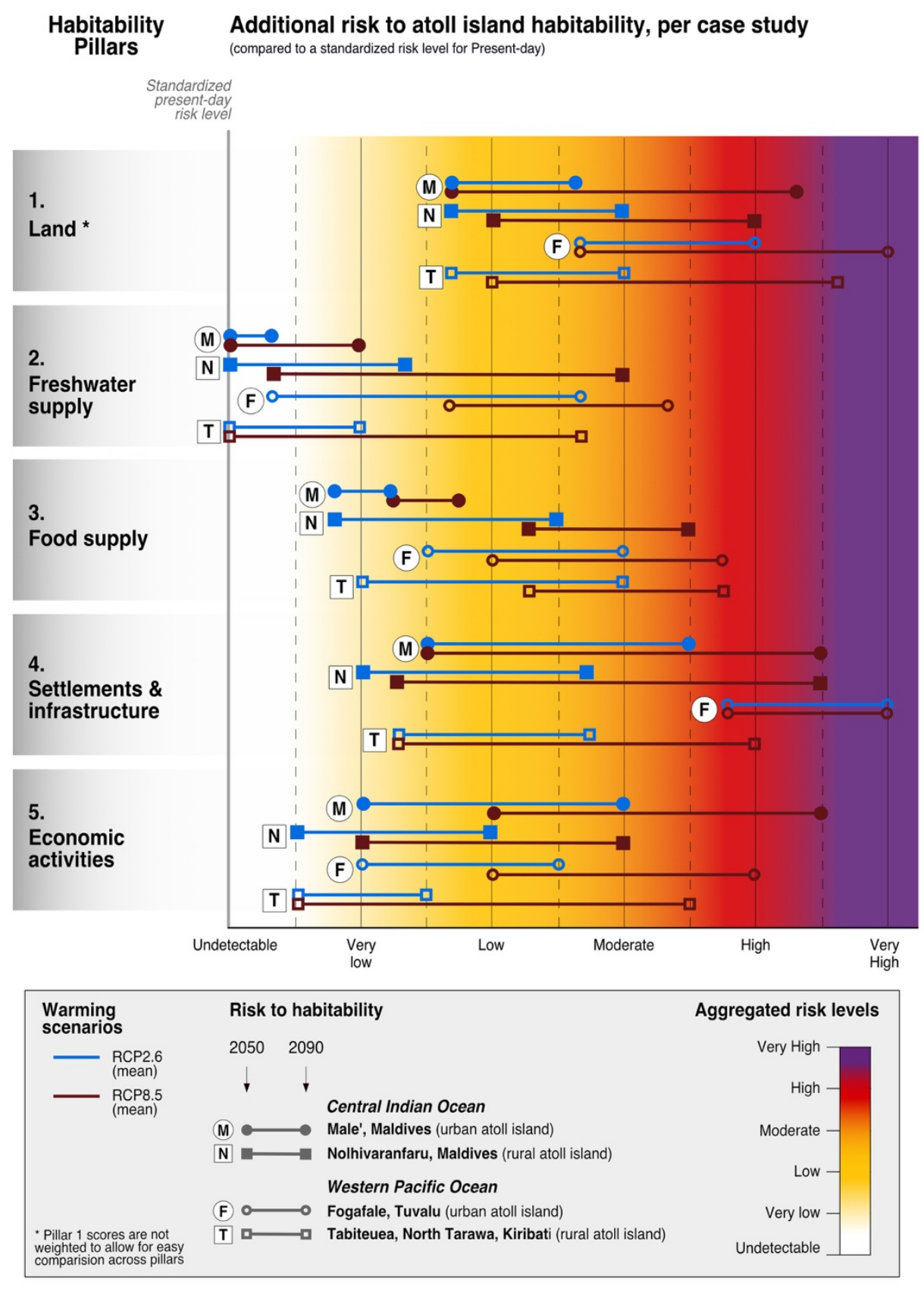

Figure 5. Additional climate risks to the five habitability pillars for four atoll islands in the Central Indian and Western Pacific Oceans.

"Additional" means additional risk to habitability compared to a present-day baseline. See Part II of the Supplementary material for details on the assessment method and results.

\subsection{Cumulative risk}

Aggregated risk levels (i.e. cross-HP; Fig. 6) are relatively comparable for Male' and the two rural islands under both RCP2.6 and RCP8.5 for both time horizons, with a slightly higher risk level for rural islands under RCP8.5 in 2090. In comparison, Fogafale exhibits much higher risk levels under both RCPs and at both time markers, due to its exceptionally flood-prone nature and exposure to other risks, especially related to Food supply (tuna fishing) and Land, with cascading impacts to the three other HPs. Generally, the aggregated risk remains close to low-to-moderate under RCP2.6 in 2090 for rural islands having no or limited coastal protection structures, increasing to relatively high 
risk under RCP8.5 in 2090. This is mainly because rural areas are more dependent on local resources and may be less able to offset impacts through imports (for Food supply) or technology (for Freshwater supply) compared to urban islands. Finally, this assessment shows that even a wellprotected urban island like Male' will experience moderate-to-high additional risk under RCP8.5 in 2090, suggesting limits to future reliance on the current heavily engineered adaptation strategy.

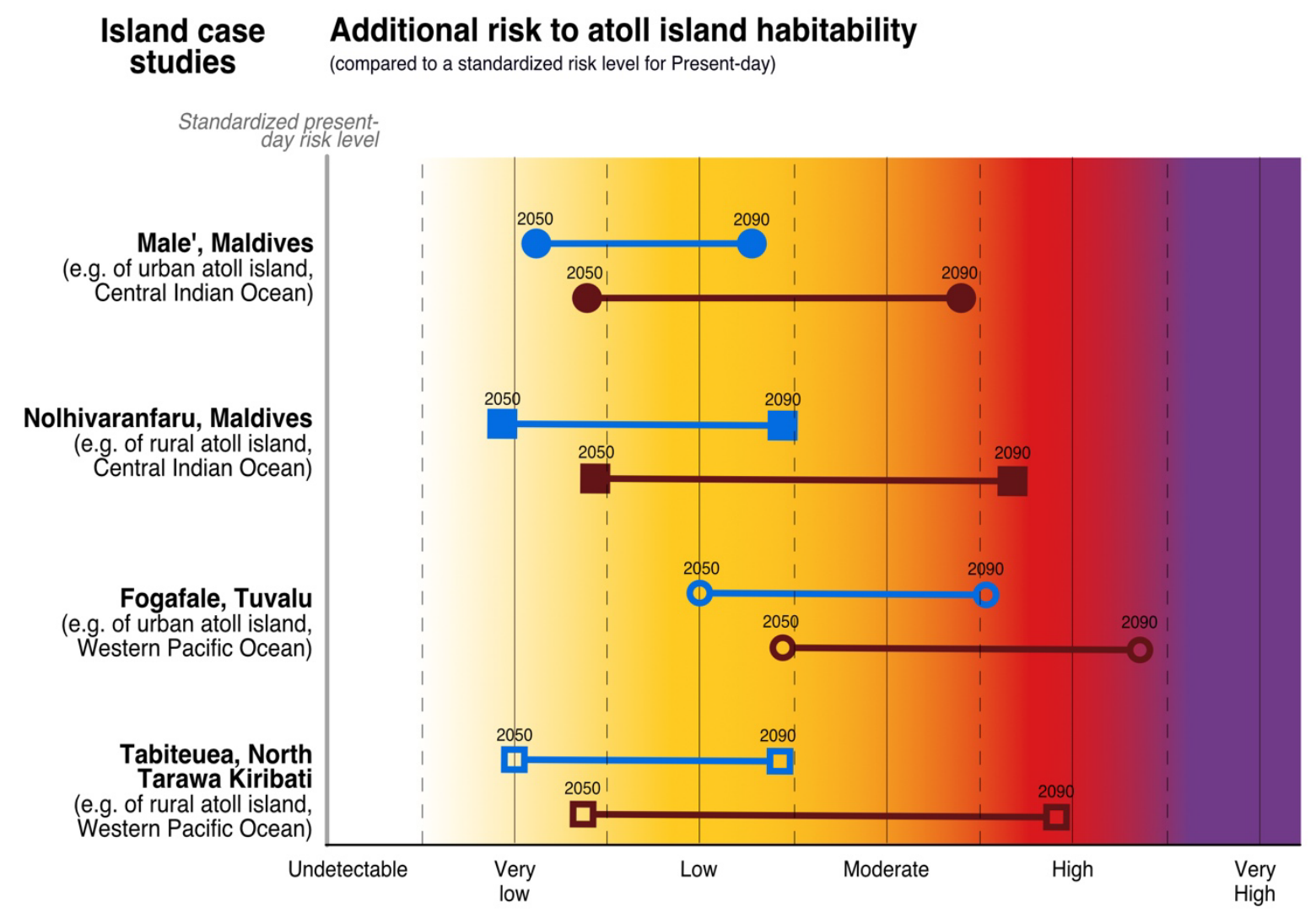

\begin{tabular}{|c|c|c|c|}
\hline $\begin{array}{l}\text { Warming } \\
\text { scenarios }\end{array}$ & \multicolumn{2}{|c|}{ Risk to habitability } & Aggregated risk levels \\
\hline - $\begin{array}{c}\mathrm{RCP} 2.6 \\
\text { (mean) }\end{array}$ & 20502090 & & Very High - \\
\hline $\begin{array}{l}\text { RCP8.5 } \\
\text { (mean) }\end{array}$ & v & Central Indian Ocean & High - \\
\hline & (M) $\longrightarrow$ & Male', Maldives (urban atoll island) & Moderate - \\
\hline & $\mathbf{N} \square$ & Nolhivaranfaru, Maldives (rural atoll island) & \\
\hline & & Western Pacific Ocean & \\
\hline & (F) 0 & Fogafale, Tuvalu (urban atoll island) & Very low - \\
\hline & $\mathbf{T} \square$ & Tabiteuea, North Tarawa, Kiribati (rural atoll island) & Undetectable \\
\hline
\end{tabular}

Figure 6. Aggregated additional climate risk to habitability for four atoll islands in the Central Indian and Western Pacific Oceans.

See especially SM8 for details on the method.

\section{DISCUSSION}

Our findings first highlight that climate change-related risk in atoll settings is driven by the cumulative and cascading effects of a large set of climate stressors on HPs. Taken together, SLR, 
extreme ENSO events, storm wave height, and coral reef degradation will cause major environmental changes on atolls from 2050 onwards under both RCP2.6 and RCP 8.5. Expected changes include shoreline erosion and increased flooding of island interiors (threats to Land) potentially leading to island physical destabilization, with multiple direct (e.g. through the deterioration of soil and FGL quality, disruption of economic activities) and indirect (e.g. through the effects of decreased FGL quality on land-based food production) cascading impacts on other HPs. Also, the declines in coastal fish stocks (and tuna and tuna-like species' biomass within the EEZs of Western Pacific nations from 2050 onwards) will significantly reduce locally-sourced fish supply. Therefore, climate risk to habitability is driven by multiple, interrelated climate stressors, where their additive effect will challenge the adaptation capacity of atolls.

Second, this study shows that climate risk to habitability will vary significantly between and within ocean basins, irrespective of the climate scenario and timescale considered. Risk will be highest in the Western Pacific. For example, Tuvalu is projected to experience (i) a high threat to Land, resulting from the cumulative effects of the highest SLR rates in atoll regions (5.1 and $15.4 \mathrm{~mm} \mathrm{yr}^{-1}$ in 2090 under RCP2.6 and RCP8.5 respectively), and increased tropical cyclone and distant-source wave height; (ii) a high threat to both Freshwater supply and land-based Food supply, as a result of increased flooding and frequency of intense droughts; (iii) the negative impacts of increased SST and ocean acidification on nearshore habitats which will reduce reef-dependent fish stocks and contribute to Land destabilization, through reef degradation and ensuing erosion; and (iv) a decrease in tuna and tuna-like resources, which will further impact Food supply from local sources. The Central Pacific (e.g. French Polynesia) is expected to be less subject to climate risk, as a result of (i) a lower increase in SST and extreme tropical cyclones having more limited impacts on the reef ecosystem and therefore on Land and land-dependent HPs, as well as on reef-based Food supply, at least until 2050; and (ii) an increase in tuna and tuna-like species in EEZs, which may offset the expected decrease in reef fish. Risk accumulation will also occur, but at a lower rate, in the Central Indian Ocean compared to the Western Pacific. However, the Maldives are projected to experience (i) increased Land destabilization (exacerbated by the small size of most islands), as a result of the combination of relatively high rates of SLR (4.6 and $15.0 \mathrm{~mm} \mathrm{yr}^{-1}$ in 2090 under RCP2.6 and RCP8.5, respectively) and increased distant-source wave height (which will increase erosion and flooding) with the highest SST values (under both RCP2.6 and RCP8.5 in 2050 and 2090) and increased frequency of extreme El Niño events (which will destabilize islands through reef degradation); (ii) the negative impacts of marine ecosystems' decline and Land destabilization on all HPs.

Third, this study highlights marked variations in climate risk to habitability across islands, depending on both their geomorphology (especially size, elevation and exposure to storms) and the effects of human activities on shoreline and island stability. This is illustrated by the comparative analysis of future risk in Fogafale (emblematic of the cumulative and destabilizing effects of climate change and human activities) and Male' (where encircling engineered structures are expected to reduce climate risk at least until 2050). Contrasts between rural islands are much lower due to limited human intervention in shoreline and island dynamics. Furthermore, our assessment shows that aggregated risk levels for rural islands are (i) lower in 2050 under both RCP2.6 and RCP8.5 compared to urban islands, especially Fogafale (Fig. 6); and (ii) higher than in Male' in 2090 under both RCP2.6 and RCP8.5. This is due to the increased degradation of ecosystems and natural resources over time, which will challenge the capacities of rural islands to offset losses through imports (for food supply) and technology (for freshwater supply and shoreline stabilization), under the moderate adaptation scenario considered.

\section{Conclusion}


This study introduces a new perspective on climate risk to future atoll island habitability. Based on an interdisciplinary assessment investigating the cumulative risk arising from multiple climate-ocean stressors -SLR; changes in rainfall, ocean-atmosphere oscillations and tropical cyclone intensity; ocean warming and acidification-, it assesses the risk caused to five major and interconnected Habitability Pillars (HPs; Land, Freshwater supply, Food supply, Settlements and Infrastructure, and Economic Activities). It does so at two spatial (ocean sub-regions and island) and temporal (2050 and 2090) scales, under the greenhouse gas concentration pathways RCP2.6 and RCP8.5 and a moderate adaptation scenario. The findings reveal that climate risk to atoll habitability is not only driven by the impacts of SLR and increased wave height on Land but rather, and importantly, by the cumulative and cascading effects of the abovementioned multiple climate stressors on these five HPs. The risk to Land, considered as the major HP (because it is the support to human life) and expected to be severe from 2050 onwards under both RCP2.6 and RCP8.5, will impact Freshwater supply from local sources, land-based Food supply, Settlements and Infrastructure, and Economic Activities. At the same time, ocean warming and acidification will increasingly contribute to Land destabilization, and decrease Food supply from local sources (including EEZs). Unless technology, human and finance capacity are significantly increased in a timely manner to effectively offset climate change impacts, the cumulative effects of climate stressors under a moderate adaptation scenario will generate impacts in the second half of the 21st century that will likely exceed the adaptive capacity of atoll islands in the Western and Central Pacific and Indian Ocean.

Our findings indicate there will be significant spatial variations in risk across both ocean basins and islands. We project that islands in the Western Pacific will experience disproportionate high risk from SLR, increased tropical cyclone and distant-source wave height, increased frequency of intense droughts, ocean warming and acidification, and a marked decrease in fish, including tuna and tunalike species. In this sub-region, the five HPs will all be significantly and simultaneously challenged, with limited compensation opportunities (e.g. through the replacement of nearshore fish catches by pelagic catches) at the nation scale. In such locations, risk accumulation is thus expected to seriously challenge atoll habitability from 2050 onwards under RCP8.5. Conversely, in the Central Pacific and Indian Ocean, risk accumulation is projected to increase at a lower rate. This is due, in the Central Pacific, to lower rates of SLR, lower exposure to tropical cyclones, lower SST and increasing pelagic fish stocks and, in the Central Indian Ocean, to lower exposure to tropical cyclones and droughts.

This study not only highlights an urgent need for future assessments of risk to atoll habitability not only to consider a wide range of climate-driven factors and island cases but also to highlight how these may differentially impact islands across ocean basins. There is also a pressing need in future work to consider how these climate drivers of risk will impact upon different adaptation scenarios and changes in non-climatic drivers of risk, so as to include other resultant habitability dimensions, especially societal health.

\section{Funding Information}

The two workshops that allowed the preparation of this paper were funded by the Agence Nationale de la Recherche (France) under the STORISK research project (No. ANR-15-CE03-0003) and by "The Ocean Solutions Initiative" supported by the Prince Albert II of Monaco Foundation, the Ocean Acidification International Coordination Centre of the International Atomic Energy Agency, the Veolia Foundation, and the French Facility for Global Environment. In addition, AKM gained support from the Agence Nationale de la Recherche (France) 'Investissement d'avenir programme' (No. ANR10-LABX-14-01) and Ademe (Convention 20ESC0016). The contribution of KLM was supported by the DFAT-funded Australia-Pacific Climate Partnership project entitled 'NextGen Climate Projections for the Western Tropical Pacific' and CSIRO. CW gained support from the Walton Family Foundation 
(grant 2018-1371), the David and Lucile Packard Foundation (grant 2019-68336), and the Gordon and Betty Moore Foundation (grant GBMF5668.02). NG was funded by The Royal Society.

\section{Acknowledgments}

The authors acknowledge the assistance of Andrew Lenton, Michael Grose, Xuebin Zhang, Claire Trenham and Mark Hemer of the CSIRO Climate Science Centre for provision of climate projection data; and Mary Taylor for support on agriculture issues.

\section{References}

ABoM \& CSIRO (2014). Climate Variability, Extremes and Change in the Western Tropical Pacific: New Science and Updated Country Reports. Pacific-Australia Climate Change Science and Adaptation Planning Program Technical Report, Australian Bureau of Meteorology and Commonwealth Scientific and Industrial Research Organization, Melbourne, Australia, 372pp.

Alam, K., \& Falkland, A. (1997). Vulnerability to Climate Change of the Bonriki Freshwater Lens, Tarawa. Report No HWR97/11, ECOWISE Environmental, ACTEW Corporation, prepared for Ministry of Environment and Social Development, Republic of Kiribati, 19pp.

Aqorau, T., Bell, J. \& Kittinger, J.N. (2018). Good governance for migratory species. Science, 361(6408), 12081209. https://doi.org/ 10.1126/science.aav2051

Asch, R.G., Cheung, W.W.L., \& Reygondeau, G. (2018). Future marine ecosystem drivers, biodiversity, and fisheries maximum catch potential in Pacific Island countries and territories under climate change. Marine Policy, 88, 285-294. https://doi.org/10.1016/j.marpol.2017.08.015

Aslam M., \& Kench, P.S. (2017). Reef Island dynamics and mechanisms of change in Huvadhoo Atoll, Republic of the Maldives, Indian Ocean. Anthropocene, 18, 57-68. https://doi.org/10.1016/j.ancene.2017.05.003

Bailey, R.T. (2015). Quantifying transient post-overwash aquifer recovery for atoll islands in the Western Pacific. Hydrological Processes, 29, 4470- 4482. https://doi.org/10.1002/hyp.10512

Bailey, R.T., \& Jenson, J.W. (2014). Effects of marine overwash for atoll aquifers: environmental and human factors. Groundwater, 52(5), 694-04. https://doi.org/10.1111/gwat.12117

Barkey, B., \& Bailey, R.,T. (2017). Estimating the Impact of Drought on Groundwater Resources of the Marshall Islands. Water, 9(1), 41. https://doi.org/10.3390/w9010041

Beetham, E., Kench, P. S., \& Popinet, S. (2017). Future Reef Growth Can Mitigate Physical Impacts of Sea-Level Rise on Atoll Islands. Earth's Future, 5 (10), 1002-1014. https://doi.org/10.1002/2017ef000589.

Beetham, E., \& Kench, P.S. (2018). Predicting wave overtopping thresholds on coral reef-island shorelines with future sea-level rise. Nature Communications, 9, 3997. https://doi.org/10.1038/s41467-018-06550

Bell, J.D., Reid, C., Batty, M.J., Allison, E.H., Lehodey, P., Rodwell, L., ... Demmke, A. (2011). Implications of climate change for contributions by fisheries and aquaculture to Pacific Island economies and communities. In J.D. Bell, J.E. Johnson, \& A.J. Hobday (Eds.), Vulnerability of tropical Pacific fisheries and aquaculture to climate change (pp.733-801). Nouméa, Secretariat of the Pacific Community.

Bell, J.D., Allain, A., Allison, E.H., Andréfouët, S., Andrew, N.L., Batty, M.J., ... Williams, P. (2015). Diversifying the use of tuna to improve food security and public health in Pacific Island countries and territories. Marine Policy, 51, 584-591. https://doi.org/10.1016/i.marpol.2014.10.005

Bell, J., Cheung, W., De Silva, S., Gasalla, M., Frusher, S., Hobday, A., ... Senina, I. (2016). Impacts and effects of ocean warming on the contributions of fisheries and aquaculture to food security. In D. Laffoley \& J. M. Baxter (Eds.), Explaining Ocean Warming: Causes, scale, effects and consequences (pp.409-437). IUCN, Gland, Switzerland.

Bell, J.D., Allain, V., Sen Gupta, A., Johnson, J.E., Hampton, J., Hobday, ... Williams, P. (2018a). Climate change impacts, vulnerabilities and adaptations: Western and Central Pacific Ocean marine fisheries. In M. Barange, T. Bahri, M.C.M. Beveridge, K.L. Cochrane, S. Funge-Smith, \& F. Poulain (Eds.), Impacts of climate change on fisheries and aquaculture: synthesis of current knowledge, adaptation and mitigation options (pp. 305-324). FAO Fisheries and Aquaculture Technical Paper No. 627. FAO, Rome.

Bell, J.D., Cisneros-Montemayor, A., Hanich, Q., Johnson, J.E., Lehodey, P., Moore, B.R., ... Wabnitz, C. (2018b). Adaptations to maintain the contributions of small scale fisheries to food security in the Pacific Islands. Marine Policy, 88, 303-314. https://doi.org/10.1016/i.marpol.2017.05.019 
Bendandi, B., \& Pauw, P. (2016). Remittances for Adaptation: An 'Alternative Source' of International Climate Finance? In A. Milan, B. Schraven, K. Warner, N. Cascone (Eds), Migration, Risk Management and Climate Change: Evidence and Policy Responses (pp. 195-211). Springer, Berlin.

Bennett, N.J., Cisneros-Montemayor, A.M., Blythe, J., Silver, J.J., Singh, G., Andrews, N., ... Sumaila, R. (2019). Towards a sustainable and equitable blue economy. Nature Sustainability, 2, 991-993. https://doi.org/10.1038/s41893-019-0404-1

Bindoff, N.L., Cheung, W.W.L., Kairo, J.G., Arístegui, J., Guinder, V.A., Hallberg, ... Williamson, P. (2019). Changing Ocean, Marine Ecosystems, and Dependent Communities. In H.-O. Pörtner, D.C. Roberts, V. Masson-Delmotte, P. Zhai, M. Tignor, E. Poloczanska et al. (Eds.), IPCC Special Report on the Ocean and Cryosphere in a Changing Climate. https://www.ipcc.ch/site/assets/uploads/sites/3/2019/11/09 SROCC Ch05 FINAL-1.pdf

Brodie, G., Brodie, J., Maata, M., Peter, M., Otiawa, T., \& Devlin, M.J. (2020). Seagrass habitat in Tarawa lagoon, Kiribati: service benefits and links to national priority issues. Marine Pollution Bulletin, 155, 111099. https://doi.org/10.1016/i.marpolbul.2020.111099

Brown, S., Wadey, M.P., Nicholls, R.J., Shareef, A., Khaleel, Z., Hinkel, J., ... McCabe, M.V. (2020). Land raising as a solution to sea-level rise: an analysis of coastal flooding on an artificial island in the Maldives. Journal of Flood Risk Management, 13 (Suppl. 1), e12567. https://doi.org/10.1111/ifr3.12567

Burns, W.C.G. (2002). Pacific Island Developing Country Water Resources and Climate Change. In P. Gleick (Ed.), The World's Water (pp. 113-132). Island Press, Washington DC.

Cagua, E. F., Collins, N., Hancock, J., \& Rees, R. (2014). Whale shark economics: a valuation of wildlife tourism in South Ari Atoll, Maldives. PeerJ, 2, e515. https://doi.org/10.7717/peerj.515

Cai, W., Borlace, S., Lengaigne, M., Van Rensch, P., Collins, M., Vecchi, G., ... Wu, L. (2014a), Increasing frequency of extreme EI Niño events due to greenhouse warming, Nature climate change, 4(2), 111116. https://doi.org/10.1038/NCLIMATE2100

Cai, W., Santoso, A.,Wang, G.,Weller, E., Wu, L., Ashok, ... Yamagata, T. (2014b). Increased frequency of extreme Indian Ocean Dipole events due to greenhouse warming. Nature, 510(7504), 254-258. https://doi.org/10.1038/nature13327

Cai, W., Wang, G., Santoso, A., McPhaden, M. J., Wu, L., Jin, ... Lengaigne, M. (2015), Increased frequency of extreme La Niña events under greenhouse warming, Nature Climate Change, 5(2), 132-137. https://doi.org/10.1038/nclimate2492

Cai, W., Wang, G., Dewitte, B., Wu, L., Santoso, A., Takahashi, K., ... McPhaden, M.J. (2018). Increased variability of eastern Pacific El Niño under greenhouse warming. Nature, 564(7735), 201-206. https://doi.org/10.1038/s41586018-0776-9

Campbell, J.R. (2015). Development, global change and traditional food security in Pacific Island countries. Regional Environmental Change, 15(7), 1313-1324. https://doi.org/10.1007/s10113-014-0697-6

Campbell, J.R. (2020). Development, Global Change and Food Security in Pacific Island Countries In J. Connell \& K. Lowitt (Eds), Food Security in Small Island States (pp.39-56). Springer, Singapore. https://doi.org/10.1007/978-981-13-8256-7 3

Canavesio, R. (2019). Distant swells and their impacts on atolls and tropical coastlines. The example of submersions produced by lagoon water filling and flushing currents in French Polynesia during 1996 and 2011 megaswells. Global and Planetary Change, 177, 116-126. https://doi.org/10.1016.j.gloplacha.2019.03.018

Chand, S. S., McBride, J. L., Tory, K. J., Wheeler, M. C., \& Walsh, K. J. E. (2013). Impact of Different ENSO Regimes on Southwest Pacific Tropical Cyclones. Journal of Climate, 26(2), 600-608. https://doi.org/10.1175/JCLI-D-12-00114.1

Charlton, K. E., Russell, J., Gorman, E., Hanich, Q., Delisle, A., Campbell, B., \& Bell, J. (2016). Fish, food security and health in Pacific Island countries and territories: a systematic literature review. BMC Public Health, 16(1), 285. https://doi.org/10.1186/s12889-016-2953-9

Chui, T.F.M, \& Terry, J. (2013). Influence of Sea-Level Rise on Freshwater Lenses of Different Atoll Island Sizes and Lens Resilience to Storm-Induced Salinization. Journal of Hydrology, 502, 18-26. https://doi.org/10.1016/i.jhydrol.2013.08.013

Chui, T.F.M., \& Terry, J.P. (2015). Groundwater salinisation on atoll islands after storm-surge flooding: modelling the influence of central topographic depressions. Water and Environment Journal, 29(3), 430438. https://doi.org/10.1111/wej.12116

Cinner, J.E., Adger, W.N., Allison, E.H., Barnes, M.L., Brown, K., Cohen, P.J., ... Morrison, T.H. (2018). Building adaptive capacity to climate change in tropical coastal communities. Nature Climate Change, 8, 117-123. https://doi.org/10.1038/s41558-017-0065-x 
Connell, J. (2014). Food security in the island Pacific: Is Micronesia as far away as ever? Regional Environmental Change, 15, 11299-1311. https://doi.org/10.1007/s10113-014-0696-7

Connell, J. (2020). Lost Roots? Fading Food Security in Micronesia In J. Connell \& K. Lowitt (Eds), Food Security in Small Island States (pp. 57-77). Singapore, Springer. https://doi.org/10.1007/978-981-13-8256-7 4

Costanza, R., Fioramonti, L., \& Kubiszewski, I. (2016). The UN Sustainable Development Goals and the dynamics of well-being. Frontiers in Ecology and the Environment, 14(2), 59-59. https://doi.org/10.1002/fee.1231

Dalton, S. J., Carroll, A. G., Sampayo, E., Roff, G., Harrison, P. L., Entwistle, K., ... Diamond, S. L. (2020). Successive marine heatwaves cause disproportionate coral bleaching during a fast phase transition from El Niño to La Niña. Science of The Total Environment, 715, 136951. 10.1016/i.scitotenv.2020.136951

Damette, O., \& Gittard, M. (2017). Climate Change and Migrations: Remittances as a Buffer? Mondes en développement, 3, 85-102. https://doi.org/10.3917/med.179.0085

Daw, T. M., Coulthard, S., Cheung, W. W., Brown, K., Abunge, C., Galafassi, D., ... \& Munyi, L. (2015). Evaluating taboo trade-offs in ecosystem services and human well-being. Proceedings of the National Academy of Sciences of the United States of America, 112(22), 6949-6954. https://doi.org/10.1073/pnas.1414900112

Deng, C. \& Bailey, R.T. (2017). Assessing groundwater availability of the Maldives under future climate conditions. Hydrological Processes, 31(19), 3334-3349. https://doi.org/10.1002/hyp.11246

Dornan, M., \& Pryke, J. (2017). Foreign Aid to the Pacific: Trends and Developments in the Twenty-First Century. Asia \& the Pacific Policy Studies, 4(3), 386-404. https://doi.org/10.1002/app5.185

Duvat, V.K.E. (2019). A global assessment of atoll island planform changes over the past decades. WIRES Climate Change, 10, e557. https://doi.org/10.1002/wcc.557.

Duvat, V.K.E., Magnan, A.K., \& Pouget, F. (2013). Exposure of atoll population to coastal erosion and flooding: a South Tarawa assessment, Kiribati. Sustainability Science, 8(3), 423-440. https://doi.org/10.1007/s11625$\underline{013-0215-7}$

Duvat, V.K.E., Magnan, A.K., Wise, R.M., Hay, J.E., Fazey, I., Hinkel, J., ... Ballu, V. (2017c). Trajectories of exposure and vulnerability of small islands to climate change. WIREs Climate Change, e478. https://doi.org/10.1002/wcc.478

Duvat, V.K.E., Salvat, B., \& Salmon, C. (2017b). Drivers of shoreline change in atoll reef islands of the Tuamotu Archipelago, French Polynesia. Global and Planetary Change, 158, 134-154. https://doi.org/i.gloplacha.2017.09.016

Duvat, V.K.E., Volto, N., \& Salmon, C. (2017a). Impacts of category 5 tropical cyclone Fantala (April 2016) on Farquhar Atoll, Seychelles Islands, Indian Ocean. Geomorphology, 298, 41-62. https://doi.org/10.1016/i.geomorph.2017.09.022

Duvat, V.K.E., \& Magnan A.K. (2019). Rapid human-driven undermining of atoll island capacity to adjust to ocean climate-related pressures. Nature Scientific Reports, 9, 15129. https://doi.org/10.1038/s41598-019$\underline{51468-3}$

Duvat, V.K.E., Pillet, V., Volto, N., Terorotua, H., \& Laurent V. (2020a). Contribution of moderate climate events to atoll island building (Fakarava Atoll, French Polynesia). Geomorphology, 354, 107057. https://doi.org/10.1016/igeomorph.2020.107057

Duvat, V.K.E., Stahl, L., Costa, S., Maquaire, O., \& Magnan, A. (2020b). Taking control of human-induced destabilisation of atoll islands: lessons learnt from the Tuamotu Archipelago, French Polynesia. Sustainability Science, 15, 569-586. https://10.1007/s11625-019-00722-8

East, H.K., Perry, C.T., Beetham, E.P., Kench, P.S., \& Liang, Y. (2020). Modelling reef hydrodynamics and sediment mobility under sea-level rise scenarios in atoll reef island systems. Global and Planetary Change, 192, 103196. https://doi.org/10.1016/j.gloplacha.2020.103196

Falkland, A. (2011). Report on Water Security \& Vulnerability to Climate Change and Other Impacts in Pacific Island Countries and East Timor. Prepared on behalf of GHD Pty Ltd for Department of Climate Change \& Energy Efficiency, Pacific Adaptation Strategy Assistance Program, August 2011, pp. 134.

Falkland, A., \& White, I. (2020). Freshwater availability under climate change In L. Kumar (Ed.), Climate Change and Impacts in the Pacific (pp. 403-448). Springer., Switzerland. https://doi.org/10.1007/978-3-030-32878$\underline{8-11}$

Fauzel, S. (2019). The impact of changes in temperature and precipitation on tourists arrival: An ARDL analysis for the case of a SIDS. Current Issues in Tourism, 1-7. https://doi.org/10.1080/13683500.2019.1639639

FFA (Pacific Islands Forum Fisheries Agency) (2017). Economic and Development Indicators and Statistics: Tuna Fisheries of the Western and Central Pacific Ocean 2016. Honiara, Pacific Islands Forum Fisheries Agency.

FFA \& SPC (2015). A Regional Roadmap for Sustainable Pacific Fisheries. Pacific Islands Forum Fisheries Agency, Honiara, and Pacific Community, Nouméa. 
Foale, M. (2003). The coconut odyssey: the bounteous possibilities of the tree of life. Australian Centre for International Agricultural Research, Canberra, pp.132.

Ford, M.R., \& Kench, P.S. (2014). Formation and adjustment of typhoon-impacted reef islands interpreted from remote imagery: Nadikdik Atoll, Marshall Islands. Geomorphology, 214, 216-222. https://doi.org/10.1016/geomorph.2014.02.006

Ford, M.R., \& Kench, P.S. (2016). Spatiotemporal variability of typhoon impacts and relaxation intervals on Jaluit Atoll, Marshall Islands. Geology, 44(2), 159-162. https://doi.org/10.1130/G37402.1

Frölicher, T. L., Fischer, E. M., \& Gruber, N. (2018). Marine heatwaves under global warming. Nature, 560 (7718), 360-364. https://doi.org/10.1038/s41586-018-0383-9

Galvis-Rodriguez, S., Post, V., Werner, A., \& Sinclair, P. (2017). Climate and Abstraction Impacts in Atoll Environments (CAIA): Sustainable management of the Bonriki Water Reserve, Tarawa, Kiribati. Secretariat of the Pacific Community, Technical Report SPC00054, Suva, Fiji, pp.142.

Gattuso, J.-P., Magnan, A., Billé, R., Cheung, W.W.L., Howes, E.L., Joos, F., ... Turley, C., (2015). Contrasting Futures for Ocean and Society from Different Anthropogenic $\mathrm{CO}_{2}$ Emissions Scenarios. Science, 349 (6243). https://doi.org/10.1126/science.aac4722

Giardino, A., Nederhoff, K., \& Vousdoukas, M. (2018). Coastal hazard risk assessment for small islands: assessing the impact of climate change and disaster reduction measures on Ebeye (Marshall Islands). Regional Environmental Change, 18 (8), 2237-2248. https://doi.org/10.1007/s10113-018-1353-3

Gischler, E. (2016). Guyot, atoll. In J. Harff, M. Meschede, S. Petersen, \& J. Thiede (Eds), Encyclopedia of Marine Geosciences (pp. 302-309), Springer, Netherlands. https://doi.org/10.1007/978-94-007-6238-1

Goldberg, W.M. (2016). Atolls of the world: Revisiting the original checklist. Atoll Research Bulletin, 610, 1-47.

Golden, C.D., Allison, E.H., Cheung, W.W., Dey, M.M., Halpern, B.S., McCauley, D.J., ... Myers, S.S. (2016). Nutrition: Fall in fish catch threatens human health. Nature, 534(7607), 317-20. https://doi.org/10.1038/534317a

Graham, N.A.J., Wilson, S.K., Carr, P., Hoey, A.S., Jennings, S. \& MacNeil, M.A. (2018). Seabirds enhance coral reef productivity and functioning in the absence of invasive rats. Nature, 559, 250-253. https://doi.org/10.1038/s41586-018-0202-3

Guinotte, J.M., Buddemeier, R.W., \& Kleypas, J. (2003). Future coral reef habitat marginality: temporal and spatial effects of climate change in the Pacific basin. Coral Reefs, 22, 551-558. https://doi.org/10.1007/s00338-003-0331-4

Harris, D., Rovere, A., Casella, E., Power, H., Canavesio, R., Collin, A. ... Parravicini, V. (2018). Coral reef structural complexity provides important coastal protection from waves under rising sea levels. Science Advances, 4(2), eaao4350. https://doi.org/10.1126/sciadv.aao4350

Hernandez-Delgado, E.A. (2015). The emerging threats of climate change in tropical coastal ecosystem services, public health, local economies and livelihood sustainability of small islands: cumulative impacts and synergies. Marine Pollution Bulletin, 101, 5-28. https://doi.org/10.1016/i.marpolbul.2015.09.018

Hicks, C.C., Cohen, P.J., Graham, N.J.A., Nash, K.L., Allison, E.H., D'Lima, C., ... MacNeil, M.A. (2019). Harnessing global fisheries to tackle micronutrient deficiencies. Nature, 574, 95-98. https://doi.org/10.1038/s41586019-1592-6

Hinkel, J., Aerts, J.C.J.H., Brown, S., Jiménez, J.A., Lincke, D., Nicholls, R.J., ... Addo, K.A. (2018). The ability of societies to adapt to twenty-first-century sea-level rise. Nature Climate Change, 8(7), 570-578. https://doi.org/10.1038/s41558-018-0176-z

Hoegh-Guldberg, O., Andréfouët, S., Fabricius, K.E., Diaz-Pulido, G., Lough, J.M., Marshall, P.A. \& Pratchett, M.S. (2011). Vulnerability of coral reefs in the tropical Pacific to climate change. In J.D. Bell, J.E. Johnson, \& A.J. Hobday (Eds.), Vulnerability of tropical Pacific fisheries and aquaculture to climate change (pp. 251296). Nouméa, Secretariat of the Pacific Community.

Hoeke, R.K., McInnes, K.L., Kruger, J., McNaught, R., Hunter, J.R. \& Smithers, S.G. (2013). Widespread inundation of Pacific islands triggered by distant-source wind-waves. Global and Planetary Change, 108, 128-138. https://doi.org/j.gloplacha.2013.06.006

Hughes, R. G., \& Lawrence, M. (2005). Globalization, food and health in Pacific Island countries. Asia Pacific Journal of Clinical Nutrition, 14(4), 298-305. PMID: 16326635

Hughes, T.P., Anderson, K.D., Connolly, S.R., Heron, S.F., Kerry, J.T., Lough, J.M., ... Wilson, S.K. (2018). Spatial and temporal patterns of mass bleaching of corals in the Anthropocene. Science, 359(6371), 80-83. https://doi.org/10.1126/science.aan8048

Hughes, D. J., Alderdice, R., Cooney, C., Kuhl, M., Pernice M., Voolstra, C. R. \& Suggett, D. J. (2020). Coral reef survival under accelerating ocean deoxygenation. Nature Climate Change, 10, 296-307.

https://doi.org/10.1038/s41558-020-0737-9 
IMF (2020). https://www.imf.org/en/News/Articles/2020/05/27/na-05272020-pacific-islands-threatened-bycovid19\#: : :text=Remittances\%20average\%20about\%2010\%20percent,the\%20COVID\%2D19\%20crisis\%20s ubsides.

IPCC (2014). Climate Change 2014: Impacts, Adaptation, and Vulnerability. Part A: Global and Sectoral Aspects. Contribution of Working Group II to the Fifth Assessment Report of the Intergovernmental Panel on Climate Change [C. Field, V.R. Barros, K.J. Mach, M.D. Mastrandrea, M. van Aalst, W.N. Adger et al. (Eds)], Cambridge University Press, Cambridge.

IPCC (2018). IPCC Special Report on Global Warming of $1.5^{\circ} \mathrm{C}$ [V. Masson-Delmotte, H.-O. Pörtner, J. Skea, P. Zhai, D. Roberts, R.S. Priyadarshi et al. (Eds.)], Cambridge University Press, Cambridge.

IPCC (2019). IPCC Special Report on the Ocean and Cryosphere in a Changing Climate [H.-O. Pörtner, D.C. Roberts, V. Masson-Delmotte, P. Zhai, M. Tignor, E. Poloczanska, et al. (Eds.)].

Jiang, M. \& DeLacy, T. (2014). A climate change adaptation framework for Pacific Island tourism. In T. DeLacy, M. Jiang, G. Lipman \& S. Vorster (Eds.), Green growth and travelism: Concept, policy and practice for sustainable tourism. Routledge, London, pp. 225.

Johnson, J. E., Allain, V., Basel, B., Bell, J. D., Chin, A., Dutra, L. X., ... Nicol, S. (2020). Impacts of Climate Change on Marine Resources in the Pacific Island Region. In L. Kumar (Ed.), Climate Change and Impacts in the Pacific (pp. 359-402). Springer, Switzerland. https://doi.org/10.1007/978-3-030-32878-8 10

Kayanne, H., Aoki, K., Suzuki, T., Hongo, C., Yamano, H., Ide, Y., ... Isobe, M. (2016). Eco-geomorphic processes that maintain a small coral reef island: Ballast Island in the Ryukyu Islands, Japan. Geomorphology, 271, 8493. https://doi.org/10.1016/i.geomorph.2016.07.021.

Kench, P.S., McLean, R.F., Brander, R.W., Nichol, S.L., Smithers, S.G., Ford, M.R., ... Aslam, M. (2006). Geological effects of tsunami on mid-ocean atoll islands: the Maldives before and after the Sumatran tsunami. Geology, 34(3), 177-180. https://doi.org/10.1130/G21907.1

Kench, P.S., Owen, S.D., \& Ford, M.R. (2014). Evidence for coral island formation during rising sea level in the central Pacific Ocean. Geophysical Research Letters, 41 (3), 820-827. https://doi.org/10.1002/2013GL059000

Kench, P.S., Beetham, E., Bosserelle, C., Kruger, J., Pohler, S., \& Coco, E.R. (2017). Nearshore hydrodynamics, beachface coble transport and morphodynamics on a Pacific atoll motu. Marine Geology, 389, 17-31. https://doi.org/10.1016/i.margeo.2017.04.012

Kleypas J. A., McManus J. W. \& Meñez L. A. B. (1999). Environmental limits to coral reef development: where do we draw the line? American Zoologist, 39(1), 146-159. https://doi.org/10.1093/icb/39.1.146

Klint, L. M., DeLacy, T., Filep, S., \& Dominey-Howes, D. (2015). Climate change and island tourism. In S. Pratt \& D. Harrison (Eds.), Tourism in Pacific Islands: Current Issues and Future Challenges (Chapter 15). Routledge, London.

Knutson, T., Camargo, S.J., Chan, J.C.L., Emanuel, K., Ho, C.-H., Kossin, J., ... Wu, L. (2019). Tropical cyclones and climate change assessment: Part I: Detection and attribution. Bulletin of the American Meteorology Society, 100, 1987-2007. https://doi.org/ 10.1175/BAMS-D-18-0189.1

Koike, H., Friedlander, A., Oleson, K., Koshiba, S., \& Polloi, K. (2014). Final report on diver's perception survey for Palau's Kemedukl and Maml. Project: Stock Assessment for humphead wrasse and humphead parrotfish, PICRC Technical Report 14-02, p.16. http://picrc.org/picrcpage/wpcontent/uploads/2016/01/WTP_Survey For_Maml Kemedukl FINAL.pdf

Krauss, K.W., McKee, K.L., Lovelock, C.E., Cahoon, D.R., Saintilan, N., \& Reef, R., Chen, L. (2014). How mangrove forests adjust to rising sea level. New Phytologist, 202, 19-34. https://doi.org/10.1111/nph.12605

Kuleshov, Y., McGree, S., Jones, D., Charles, A., Cottril, A., Prakash, B., ... Seuseu, S.K. (2014). Extreme Weather and Climate Events and Their Impacts on Island Countries in the Western Pacific: Cyclones, Floods and Droughts. Atmospheric and Climate Sciences, 4, 803-818. https://doi.org/10.4236/acs.2014.45071

Kulp, S.A., \& Strauss, B.H. (2019). New elevation data triple estimates of global vulnerability to sea-level rise and coastal flooding. Nature Communication, 10, 4844. https://doi.org/10.1038/s41467-019-12808-z

Kumar, L., Eliot, I., Nunn, P.D., Stul, T., \& McLean, R. (2018). An indicative index of physical susceptibility of small islands to coastal erosion induced by climate change: an application to the Pacific islands. Geomatics, Natural Hazards and Risk, 9(1), 691-702. https://doi.org/10.1080/19475705.2018.1455749

Kumar, L., \& Taylor, S. (2015). Exposure of coastal built assets in the South Pacific to climate risks. Nature Climate Change, 5 (11), 992-996. https://doi.org/10.1038/nclimate2702

Lam, V.W.Y., Allison, E.H., Bell, J.D., Blythe, J., Cheung, W.W.L., Frolicher, ... M.A., Sumaila, U.R. (2020). Climate change, tropical fisheries and prospects for sustainable development. Nature Reviews Earth and Environment. https://doi.org/10.1038/s43017-020-0071-9 
Lecomte, M., Rochette J., Laurans Y., \& Lapeyre R. (2017). Indian Ocean tuna fisheries: between development opportunities and sustainability issues. Paris, IDDRI Report, 96 p. URL :

https://www.iddri.org/sites/default/files/PDF/Publications/Hors\%20catalogue\%20lddri/201811-tunaindian\%20oceanEN.pdf

Lovell S.A. (2011). Health governance and the impact of climate change on Pacific small island developing states. In Human Health and Global Environmental Change. Magazine of the International Human Dimensions Programme on Global Environmental Change, 1 (pp.50-55), ISSN 1727-155X.

Lovelock, C.E., Cahoon, D.R., Friess, D.A., Guntenspergen, G.R., Krauss, K.W., Reef, R., ... Triet, T. (2015). The vulnerability of Indo-Pacific mangrove forests to sea-level rise. Nature, 526, 559-563. https://doi.org/10.1038/nature15538

Lorrey, A.M., \& Renwick, J.A. (2011). Assessment of the 2010-11 Southwest Pacific Drought. Report prepared for the New Zealand Ministry of Foreign Affairs and Trade, October 2011. National Institute of Water \& Atmospheric Research Ltd, Auckland, N.Z., pp.20.

MacNeil, M.A., Graham, N.A.J., Cinner, J.E., Wilson, S.K., Williams, I.D., Maina, J., ... McClanahan, T.R. (2015). Recovery potential of the world's coral reef fishes. Nature, 520, 341-344. https://doi.org/10.1038/nature14358

Magnan, A.K., Ranché, M., Duvat, V.K.E., Prenveille, A., \& Rubia, F. (2019). L'exposition des populations des atolls de Rangiroa et de Tikehau (Polynésie française) au risque de submersion marine. VertigO, 18(31). https://doi.org/10.4000/vertigo.23607

Magnan A. K., Garschagen M., Gattuso J.-P., Hay J. E., Hilmi N., Holland E., ... van de Wal R. (2019). Integrative cross-chapter box on low-lying islands and coasts. In: H.-O. Pörtner, D. Roberts, V. Masson-Delmotte \& P. Zhai (Eds.), IPCC Special Report on Ocean and Cryosphere in a Changing Climate (pp. 657-674). https://www.ipcc.ch/site/assets/uploads/sites/3/2019/11/11 SROCC CCB9-LLIC FINAL.pdf

McClanahan, T.R., Graham, N.A.J., MacNeil, M.A., Muthiga, N.A., Cinner, J.E., Bruggemann, J.H., \& Wilson, S.K. (2011). Critical thresholds and tangible targets for ecosystem-based management of coral reef fisheries. Proceedings of the National Academy of Sciences of the USA, 108, 17230-17233. https://doi.org/10.1073/pnas.1106861108

McLean, R.F. (2011). Atoll islands (motu) In D. Hopley (Ed.), Encyclopedia of modern coral reefs: structures, form and process (pp 47-51). Springer, Science+Business Media B.V. https://doi.org/10.1007/978-90-481$\underline{2639-2}$

McLean, R.F. \& Kench, P. S. (2015). Destruction or persistence of coral atoll islands in the face of 20th and 21st century sea-level rise? WIREs Climate Change, 6, 445-463. https://doi.org/10.1002/wcc.350

Mechler, R., Singh, C., Ebi, K., Djalante, R., Thomas, A., James, R., ... Revi, A. (2020). Loss and Damage and limits to adaptation : recent IPCC insights and implications for climate science and policy. Sustainability Science, 15, 1245-1251. https://doi.org/10.1007/s11625-020-00807-9

Mentaschi, L., Vousdoukas, M.I., Voukouvalas, E., Dosio, A., \& Feyen, L. (2017). Global changes of extreme coastal wave energy fluxes triggered by intensified teleconnection patterns. Geophysical Research Letters, 44, 2416-2426, https://doi.org/10.1002/2016GL072488

Milan A., Oakes R., \& Cambell J. (2016). Tuvalu: climate change and migration. Relationships between household vulnerability, human mobility and climate change. ESCAP Report No. 18, Bonn: United Nations University Institute for Environment and Human Security (UNU-EHS), pp.80. https://collections.unu.edu/eserv/UNU:5856/Online_No_18_Tuvalu_Report_161207_pdf

Ministry of Tourism (2018). Tourism Yearbook 2018. Statistics and Research Section, Ministry of Tourism. Male, Maldives, pp.66.

Morgan, K.M., \& Kench, P.S. (2014). A detrital sediment budget of a Maldivian reef platform. Geomorphology, 222, 122-131. https://doi.org/ 10.1016/i.geomorph.2014.02.013

Morim, J., Hemer, M., Cartwright, N., Strauss, D., \& Andutta, F. (2018). On the concordance of 21st century wind-wave climate projections. Global and Planetary Change, 167, 160-171. https://doi.org/10.1016/j.gloplacha.2018.05.005

Morim, J., Hemer, M., Xiaolan, L.W., Cartwright, N., Trenham, C., Semedo, A., ... Andutta, F. (2019). Robustness and uncertainties in global multivariate wind-wave climate projections, Nature Climate Change, 9(9), 711718. http://doi.org/10.1038/s41558-019-0542-5

Murakami, H., Delworth, T.L., Cooke, W.F., Zhao, M., Xiang, B., \& Hu, P-C. (2020). Detected climatic change in global distribution of tropical cyclones. Proceedings of the National Academy of Sciences of the United States of America, 117(20), 10706-10714. https://doi.org/10.1073/pnas.1922500117

Musah-Surugu, I. J., Ahenkan, A., Bawole, J. N., \& Darkwah, S. A. (2018). Migrants' remittances: A complementary source of financing adaptation to climate change at the local level in Ghana. International 
Journal of Climate Change Strategies and Management, 10(1), 178-196. https://doi.org/10.1108/IJCCSM03-2017-0054

Naylor, A.K. (2015). Island morphology, reef resources, and development in the Maldives. Progress in Physical Geography, 39(6), 728-749. https://doi.org/10.1177/0309133315598269

Nunn, P. D. (2007). Climate, Environment and Society in the Pacific during the Last Millennium. Elsevier, Amsterdam.

Nunn, P. D. \& Kumar, R. (2018). Understanding climate-human interactions in Small Island Developing States (SIDS): implications for future livelihood sustainability. International Journal of Climate Change Strategies and Management, 10, 245-271. https://doi.org/10.1108/IJCCSM-01-2017-0012

Nunn, P. D. \& Kumar, R. (2019). Cashless adaptation to climate change in developing countries: unwelcome yet unavoidable? One Earth, 1, 31-34. https://doi.org/10.1016/j.oneear.2019.08.004

Nurse, L.A., McLean, R.F., Agard, J., Briguglio, L.P., Duvat-Magnan, V., Pelesikoti, N., ... Webb, A. (2014). Small islands. In V.R. Barros, C.B. Field, D.J. Dokken, M.D. Mastrandrea, K.J. Mach, T.E. Bilir, et al. (Eds.), Climate Change 2014: Impacts, Adaptation, and Vulnerability. Part B: Regional Aspects (pp.1613-1654). Contribution of Working Group II to the Fifth Assessment Report of the Intergovernmental Panel on Climate Change. Cambridge University Press, Cambridge.

OECD (2015). Small island developing states (SIDS) and the post-2015 development finance agenda. Third International Conference on Financing for Development. https://www.oecd.org/dac/financing-sustainabledevelopment/Addis\%20Flyer\%20SIDS\%20FINAL.pdf

Oppenheimer, M., Glavovic, B., Hinkel, J., Van De Wal, R., Magnan, A., Abd-Elgawad, ... Sebesvari, Z. (2019). Sea Level Rise and Implications for Low Lying Islands, Coasts and Communities. In H.-O. Pörtner, D.C. Roberts, V. Masson-Delmotte, P. Zhai, M. Tignor, E. Poloczanska, et al. (Eds.). IPCC Special Report on the Ocean and Cryosphere in a Changing Climate._ https://report.ipcc.ch/srocc/pdf/SROCC FinalDraft Chapter4.pdf

Owen, S.D., Kench, P. S. \& Ford, M. (2016). Improving understanding of the spatial dimensions of biophysical change in atoll island countries and implications for island communities: a Marshall Islands' case study. Applied Geography, 72, 55-64. https://doi.org/10.1016/j.apgeog.2016.05.004

Perry, C.T., Kench, P.S., Smithers, S.G., Riegl, B., Yamano, H. \& O'Leary, M.J. (2011). Implications of reef ecosystem change for the stability and maintenance of coral reef islands. Global Change Biology, 17(12), 3679-3696. https://doi.org/10.1111/j.1365-2486.2011.02523.x

Perry, C.T., Kench, P.S., Smithers, S.G., Yamano, H., O'Leary, M., \& Gulliver, P. (2013).Time scales and modes of reef lagoon infilling in the Maldives and controls on the onset of reef island formation. Geology, 41(10), 1111-1114. https://doi.org/10.1130/G34690.1

Perry, C.T., Alvarez-Filip, L., Graham, N.A.J., Mumby, P.J., Wilson, S.K., Kench, P.S., ... Macdonald, C. (2018). Loss of coral reef growth capacity to track future increases in sea level. Nature, 558(7710), 396-400. https://doi.org/10.1038/s41586-018-0194-z

Perry, C.T., Morgan, K.M., Lange, I.D., \& Yarlett, R.T. (2020). Bleaching-driven reef community shifts drive pulses of increased reef sediment generation. Royal Society-Open Science 7, 192153. http://doi.org/10.1098/rsos.192153

Pew (2016) Netting billions: a global valuation of tuna. A report from the PEW Charitable Trust. URL: https://www.pewtrusts.org/en/research-and-analysis/reports/2016/05/netting-billions-a-global-valuationof-tuna

Pinsky, M. L., Reygondeau, G., Caddell, R., Abrantes, J.P., Spijkers, J \& Cheung, W.W.L. (2018). Preparing ocean governance for species on the move. Science, 360(6394), 1189-1191. https://doi.org/ $10.1126 /$ science.aat2360

Pratchett, M.S., Munday, P.L., Graham, N.A.J., Kronen, M., Pinca, S., Friedman, K., ... Cinner, J.E. (2011). Vulnerability of coastal fisheries in the tropical Pacific to climate change. In: J.D. Bell, J.E. Johnson \& A.J. Hobday (Eds), Vulnerability of tropical Pacific fisheries and aquaculture to climate change (pp. 494-576). Nouméa, Secretariat of the Pacific Community.

Pratchett, M.S., Hoey, A.S. \& Wilson, S.K. (2014). Reef degradation and the loss of critical ecosystem goods and services provided by coral reef fishes. Current Opinion in Environmental Sustainability, 7, 37-43 https://doi.org/10.1016/i.cosust.2013.11.022

Quataert, E., Storlazzi, C., van Rooijen, A., Cheriton, O., \& van Dongeren, A. (2015). The influence of coral reefs on wave-driven flooding of tropical coastlines. Geophysical Research Letters, 42, 6407-6415. https://doi.org/10.1002/2015GL064861

Quigley, N., Beavis, S.G., \& White, I. (2016). Rainwater harvesting augmentation of domestic water supply in Honiara, Solomon Islands. Australian Journal of Water Resources, 20, 65-77.

http://dx.doi.org/10.1080/13241583.2016.1173314 
Robinson, J.P.W., Wilson, S.K., Jennings, S., \& Graham, N.A.J. (2019a). Thermal stress induces persistently altered coral reef fish assemblages. Global Change Biology, 25, 2739-2750. https://doi.org/10.1111/gcb.14704

Robinson, J.P.W., Wilson, S.K., Robinson, J., Gerry, C., Lucas, J., Assan, C., ... Graham, N.A.J. (2019b). Productive instability of coral reef fisheries after climate-driven regime shifts. Nature Ecology and Evolution, 3, 183190. https://doi.org/10.1038/s41559-018-0715-z

Roy, J., Tschakert, P., Waisman, H., Abdul Halim, S., Antwi-Agyel, P., Dasguta, P., ... Suarez Rodriguez, A.G. (2018). Sustainable development, poverty eradication and reducing inequalities. In: V. Masson-Delmotte (Ed.), Global warming of $1.5^{\circ} \mathrm{C}$. An IPCC Special Report on the impacts of global warming at $1.5^{\circ} \mathrm{C}$ above preindustrial levels and related greenhouse gas emission pathways, in the context of strengthening the global response to the threat of climate change, sustainable development, and efforts to eradicate poverty. IPCC, Geneva.

Sale, O.F., Agardy, T., Ainsworth, C.H., Feist, B.E., Bell, J.D., Christie, P., ... Sheppard, C.R.C. (2014). Transforming management of tropical coastal seas to cope with challenges of the 21st century. Marine Pollution Bulletin, 85, 8-23. https://doi.org/10.1016/j.marpolbul.2014.06.005

Savage, A., Mclver, L., \& Schubert, L. (2020). The nexus of climate change, food and nutrition security and dietrelated non-communicable diseases in Pacific Island Countries and Territories. Climate and Development, 12(2), 120-133. https://doi.org/10.1080/17565529.2019.1605284

Schuerch M., Spencer, T., Temmerman, S., Kirwan, M.L., Wolff, C., Lincke, D., ... Brown, S. (2018). Future response of global coastal wetlands to sea-level rise. Nature, 561, 231-234. https://doi.org/10.1038/s41586-018-0476-5

Scoffin, T.P. (1993). The geological effects of hurricanes on coral reefs and interpretation of storm deposits. Coral Reefs, 12, 203-221. https://doi.org/10.1007/BF00334480

Seetanah, B., \& Fauzel, S. (2019). Investigating the impact of climate change on the tourism sector: evidence from a sample of island economies. Tourism Review, 74(2), 194-203. https://doi.org/10.1108/TR-12-2017$\underline{0204}$

Shope, J. B., Storlazzi, C.D., \& Hoeke, R. K. (2017). Projected atoll shoreline and run-up changes in response to sea-level rise and varying large wave conditions at Wake and Midway Atolls, Northwestern Hawaiian Islands. Geomorphology, 295, 537-550. https://doi.org/10.1016/i.geomorph.2017.08.002

Shope, J. B., \& Storlazzi, C.D. (2019). Assessing Morphologic Controls on Atoll Island Alongshore Sediment Transport Gradients Due to Future Sea-Level Rise. Frontiers in Marine Science, 6, 245. https://doi.org/10.3389/fmars.2019.00245

Sievert, K., Lawrence, M., Naika, A., \& Baker, P. (2019). Processed Foods and Nutrition Transition in the Pacific: Regional Trends, Patterns and Food System Drivers. Nutrients, 11(6), 1328. https://doi.org/10.3390/nu11061328

SPC (2019). Implications of climate-driven redistribution of tuna on Pacific Island economies. SPC Policy Brief 32/2019. Pacific Community, Nouméa.

Speelman, L. H., Nicholls, R. J., \& Dyke, D.J. (2017). Contemporary migration intentions in the Maldives: the role of environmental and other factors. Sustainability Science, 12(3), 433-451. https://doi.org/10.1007/s11625-016-0410-4

Spennemann, D.H.R. (1996). Nontraditional settlement patterns and typhoon hazard on contemporary Majuro Atoll, Republic of the Marshall Islands. Environmental Management, 20(3), 337-348.

Spennemann, D.H.R. (2009). Hindcasting typhoons in Micronesia: experiences from ethnographic and historic records. Quaternary International, 195, 106-121. https://doi.org/10.1016/j.quaint.2007.08.042

Storlazzi, C.D., Gingerich, S.B., van Dongeren, A., Cheriton, O.M., Swarzenski, P.W., Quataert, E., Voss, C.I., ... McCall, R. (2018). Most atolls will be uninhabitable by the mid- $21^{\text {st }}$ century because of sea-level rise exacerbating wave-driven flooding. Science Advances, 4 (4). https://doi.org/10.1126/sciadv.aap9741

Taylor, K.E., Stouffer, R.J. \& Meehl, G.A. (2012). An Overview of CMIP5 and the Experiment Design. Bulletin of the American Meteorological Society, 93(4), 485-498. https://doi.org/10.1175/BAMS-D-11-00094.1

Taylor, M., McGregor, A, \& Dawson, B (Eds.) (2016). Vulnerability of Pacific Island Agriculture and Forestry to Climate Change. Pacific Community, Nouméa.

Thaman, R. (1995). Urban food gardening in the Pacific Islands: A basis for food security in rapidly urbanising small-island states. Habitat International, 19(2), 209-224. https://doi.org/10.1016/0197-3975(94)00067-C

Thow, A. M., \& Snowdon, W. (2010). The effect of trade and trade policy on diet and health in the Pacific Islands In C. Hawkes, C. Blouin, H. Spencer, N. Drager, \& L. Dube (Eds.), Trade, food, diet and health: Perspectives and policy options (pp. 147-168). Blackwell Publications, Chichester. 
Thow, A.M., Swinburn, B., Colagiuri, S., Diligolevu, M., Quested, C., Vivili, P., \& Leeder, S. (2010). Trade and food policy: case studies from three Pacific Island countries. Food Policy, 35(6), 556-564. https://doi.org/10.1016/j.foodpol.2010.06.005

Tuck, M., Kench, P.S., Ford, M.R., \& Masselink, G. (2019). Physical modelling of the response of reef islands to sea level rise. Geology, 479, 803-806. https://doi.org/10.1130/G46362

UNFCCC (2005). Climate change: Small Island Developing States. Bonn, Germany, UNFCCC Secretariat.

UNICEF \& WHO (2019). Progress on household drinking water, sanitation and hygiene 2000-2017. Special focus on inequalities. United Nations Children's Fund and World Health Organization, New York, pp.138.

van der Veeken, S., Calgaro, E., Munk Klint, L., Law, A., Jiang, M., de Lacy, T., \& Dominey-Howes, D. (2015). Tourism destinations' vulnerability to climate change: Nature-based tourism in Vava'u, the Kingdom of Tonga. Tourism and Hospitality Research, 16(1), 50-71. https://doi.org/10.1177/1467358415611068

van Hooidonk, R., Maynard, J., Tamelander, J., Gove, J., Ahmadia, G., Raymundo, L., et al. (2016). Local-scale projections of coral reef futures and implications of the Paris Agreement. Scientific Reports, 6, 39666. https://doi.org/10.1038/srep39666

Vitousek, S., Barnard, P.L., Fletcher, C.H., Frazer, N., Erikson, L., \& Storlazzi, C.D. (2017). Doubling of coastal flooding frequency within decades due to sea-level rise. Scientific Reports, 7(1), 1399. https://doi.org/10.1038/s41598-017-01362-7

Wadey, M., Brown, S., Nicholls, R. J. \& Haigh, I. (2017). Coastal flooding in the Maldives: an assessment of historic events and their implications. Natural Hazards, 89, 131-159. https://doi.org/10.1007/s11069-0172957-5

Walsh, K.J.E., McInnes, K.L., \& McBride, J.L. (2012). Climate change impacts on tropical cyclones and extreme sea levels in the South Pacific: A regional assessment. Global and Planetary Change, 80-81, 149-164. https://doi.org/10.1016/j.gloplacha.2011.10.006

Waycott, M., McKenzie, L.J., Mellors, J.E., Ellison, J.C., Sheaves, M.T., Collier, C., ... Payri, C.E. (2011). Vulnerability of coral reefs in the tropical Pacific to climate change. In J.D. Bell, J.E. Johnson \& A.J. Hobday (Eds), Vulnerability of Tropical Pacific Fisheries and Aquaculture to Climate Change. Nouméa, Secretariat of the Pacific Community.

Weatherdon, L.V., Magnan, A.K., Rogers, A.D., Sumaila, U.R. \& Cheung, W.W.L. (2016). Observed and Projected Impacts of Climate Change on Marine Fisheries, Aquaculture, Coastal Tourism, and Human Health: An Update. Frontiers in Marine Science, 3, 48. https://doi.org/10.3389/fmars.2016.00048

Webb, A., \& Kench, P.S. (2010). The dynamic responses of reef islands to sea-level rise: evidence from multidecadal analysis of island change in the Central Pacific. Global and Planetary Change, 72, 234-246. https://doi.org/10.1016/i.gloplacha.2010.05.003

Weisler, M.I. (1999). Atolls as settlement landscapes: Ujae, Marshall Islands. Atoll Research Bulletin, 460, 53 p.

Weyer, N.M, Cifuentes-Jara, M., Frölicher, T., Jackson, M., Kudela, R.M., Masson-Delmotte, V., ... Zhai, P. (2019). Sea Level Rise and Implications for Low Lying Islands, Coasts and Communities. In H.-O. Pörtner, D.C. Roberts, V. Masson-Delmotte, P. Zhai, M. Tignor, E. Poloczanska, et al. (Eds.), IPCC Special Report on the Ocean and Cryosphere in a Changing Climate https://www.ipcc.ch/site/assets/uploads/sites/3/2019/09/SROCC FinalDraft Annex 1 Glossary.pdf

White, I., \& Falkland, A. (2010). Management of freshwater lenses on small Pacific islands. Hydrogeology Journal, 18, 227-246. https://doi.org/10.1007/s10040-009-0525-0.

White, I., Falkland, A., Metutera, T., Metai, E., Overmars, M., Perez, P., \& Dray, A. (2007). Climatic and human influences on groundwater in low atolls. Vadose Zone Journal, 6, 581-590. https://doi.org/10.2136/vzj2006.0092

WHO (2015). Human health and climate change in Pacific Island countries. World Health Organization Regional Office for the Western Pacific. ISBN-13 9789290617303 (NLM Classification: WA 30.5), pp. 145, Switzerland.

Widlansky, M.J., Marra, J.J., Chowdhury, M.R., Stephens, S.A., Miles, E.R., Fauchereau, N., ... Beard, G. (2017). Future extreme sea level seesaws in the tropical Pacific. Climate Change. Journal of Applied Meteorological and Climatology, 56(4), 849-862. https://doi.org/10.1126/sciadv.1500560

Wielgus J., Chadwick-Furman, N.E., Dubinsky, Z., Shechter, M., \& Zeitouni N. (2002). Dose-response modeling of recreationally important coral-reef attributes: a review and potential application to the economic valuation of damage. Coral Reefs, 21(3), 253-259. https://doi.org/10.1007/s00338-002-0243-8

Williams, M., \& McDuie-Ra, D. (2018). Organizing Climate Finance in the Pacific. In M., Williams, \& D. McDuieRa (Eds.), Combatting Climate Change in the Pacific (pp. 87-108). Springer, Switzerland. https://doi.org/10.1007/978-3-319-69647-8 
Woodroffe, C.D. (2008). Reef-island topography and the vulnerability of atolls to sea-level rise. Global and Planetary Change, 62, 77-96. https://doi.org/10.1016/i.gloplacha.2007.11.001

World Bank (2017). Pacific Possible : long-term economic opportunities and challenges for Pacific Island Countries. Pacific possible series. Washington D.C., World Bank Group.

http://documents.worldbank.org/curated/en/168951503668157320/Pacific-Possible-long-term-economicopportunities-and-challenges-for-Pacific-Island-Countries

Yadav, S., Abdulla, A., Bertz, N. \& Mawyer, A. (2019). King tuna: Indian Ocean trade, offshore fishing, and coral reef resilience in the Maldives archipelago. ICES Journal of Marine Sciencen 77(1), 398-407. https://doi.org/10.1093/icesjms/fsz170

Yamano, H., Kayenne, H., Yamaguchi, T., Kuwahara, Y., Yokoki, H., Shimazaki, H., \& Chikamori, M. (2007). Atoll island vulnerability to flooding and inundation revealed by historical reconstruction: Fongafale Islet, Funafuti Atoll, Tuvalu. Global and Planetary Change, 57, 407-416. https://doi.org/10.1016/i.gloplacha.2007.02.007

Zimmerhackel, J. S., Kragt, M. E., Rogers, A.A., Ali, K., \& Meekan, M. G. (2019). Evidence of increased economic benefits from shark-diving tourism in the Maldives. Marine Policy, 100, 21-26.

https://doi.org/10.1016/i.marpol.2018.11.004 